\title{
Secondary organic aerosol formation from idling gasoline passenger vehicle emissions investigated in a smog chamber
}

\author{
E. Z. Nordin ${ }^{1}$, A. C. Eriksson ${ }^{2}$, P. Roldin ${ }^{2}$, P. T. Nilsson ${ }^{1}$, J. E. Carlsson ${ }^{1}$, M. K. Kajos ${ }^{3}$, H. Hellén ${ }^{4}$, C. Wittbom ${ }^{2}$, \\ J. Rissler ${ }^{1}$, J. Löndahl ${ }^{1}$, E. Swietlicki ${ }^{2}$, B. Svenningsson ${ }^{2}$, M. Bohgard ${ }^{1}$, M. Kulmala ${ }^{2,3}$, M. Hallquist ${ }^{5}$, and \\ J. H. Pagels ${ }^{1}$ \\ ${ }^{1}$ Ergonomics and Aerosol Technology, Lund University, P.O. Box 118, 22100 Lund, Sweden \\ ${ }^{2}$ Division of Nuclear Physics, Lund University, P.O. Box 118, 22100 Lund, Sweden \\ ${ }^{3}$ Department of Physics, University of Helsinki, P.O. Box 64, 00014 Helsinki, Finland \\ ${ }^{4}$ Finnish Meteorological Institute, P.O. Box 503, FIN-00101 Helsinki, Finland \\ ${ }^{5}$ Department of Chemistry, Atmospheric Science, University of Gothenburg, 41296 Gothenburg, Sweden
}

Correspondence to: E. Z. Nordin (erik.nordin@design.lth.se)

Received: 14 November 2012 - Published in Atmos. Chem. Phys. Discuss.: 11 December 2012

Revised: 8 May 2013 - Accepted: 22 May 2013 - Published: 28 June 2013

\begin{abstract}
Gasoline vehicles have recently been pointed out as potentially the main source of anthropogenic secondary organic aerosol (SOA) in megacities. However, there is a lack of laboratory studies to systematically investigate SOA formation in real-world exhaust. In this study, SOA formation from pure aromatic precursors, idling and cold start gasoline exhaust from three passenger vehicles (EURO2-EURO4) were investigated with photo-oxidation experiments in a $6 \mathrm{~m}^{3}$ smog chamber. The experiments were carried out down to atmospherically relevant organic aerosol mass concentrations. The characterization instruments included a high-resolution aerosol mass spectrometer and a proton transfer mass spectrometer. It was found that gasoline exhaust readily forms SOA with a signature aerosol mass spectrum similar to the oxidized organic aerosol that commonly dominates the organic aerosol mass spectra downwind of urban areas. After a cumulative $\mathrm{OH}$ exposure of $\sim 5 \times 10^{6} \mathrm{~cm}^{-3} \mathrm{~h}$, the formed SOA was 1-2 orders of magnitude higher than the primary OA emissions. The SOA mass spectrum from a relevant mixture of traditional light aromatic precursors gave $f_{43}$ (mass fraction at $m / z=43$ ), approximately two times higher than to the gasoline SOA. However $\mathrm{O}: \mathrm{C}$ and $\mathrm{H}: \mathrm{C}$ ratios were similar for the two cases. Classical $\mathrm{C}_{6}-\mathrm{C}_{9}$ light aromatic precursors were responsible for up to $60 \%$ of the formed SOA, which is significantly higher than for diesel exhaust. Important candidates for additional precursors are higherorder aromatic compounds such as $\mathrm{C}_{10}$ and $\mathrm{C}_{11}$ light aro-
\end{abstract}

matics, naphthalene and methyl-naphthalenes. We conclude that approaches using only light aromatic precursors give an incomplete picture of the magnitude of SOA formation and the SOA composition from gasoline exhaust.

\section{Introduction}

The formation mechanisms, magnitude and chemical composition of secondary organic aerosol (SOA) are of importance for predicting future climate scenarios (Monks et al., 2009; Hallquist et al., 2009). There is a lack of knowledge about how SOA affects public health, though the association between concentration of fine particles and mortality is stronger in the summer (Nawrot et al., 2007), which is also when the SOA production is increased (Hallquist et al., 2009). SOA is formed from low vapor pressure reaction products, which originate from gas-phase oxidation of volatile organic compounds (VOCs). De Gouw and Jimenez (2009) suggested that SOA from urban sources may be the dominant source of organic aerosol globally between $30^{\circ}$ and $50^{\circ}$ latitude.

Traditionally the VOCs responsible for the majority of urban SOA formation have been assumed to be light aromatic hydrocarbons, which are hydrocarbons with one benzene ring, often with one or more alkyl groups (methyl, ethyl or propyl), i.e., benzene $\left(\mathrm{C}_{6}\right)$, toluene $\left(\mathrm{C}_{7}\right)$, xylenes and ethyl benzene $\left(\mathrm{C}_{8}\right)$, and $\mathrm{C}_{9}$ and $\mathrm{C}_{10}$ aromatics (Odum et al., 1997). 
Robinson et al. (2007) recognized intermediate-volatility organic compounds (IVOCs) and semi-volatility organic compounds (SVOCs) as important sources for production of ambient organic aerosol. Photo-oxidation experiments of exhaust from a diesel generator indicated that only a small fraction of the formed SOA originated from light aromatic precursors (Weitkamp et al., 2007). They also suggested that IVOCs such as long-chain and branched alkanes could be responsible for a large fraction of the SOA produced from diesel exhaust. However, recent smog chamber studies suggest that the SOA formation from modern diesel vehicles with functioning oxidation catalysts is very low (Chirico et al., 2010; Samy and Zielinska, 2010).

Less attention has been paid to SOA formation from gasoline exhaust, although VOC emissions can be high during cold starts, increasing with decreasing ambient temperature. At ambient temperatures below $0{ }^{\circ} \mathrm{C}$ the VOC emissions from the start-up phase can be equivalent to thousands of driven kilometers; since the emissions during driving have been further reduced, this figure is most likely even higher for newer vehicles (Weilenmann et al., 2009). This is due to fuel condensing on the inner surface of the cylinder when the engine temperature is low, causing a fuel-rich incomplete combustion, but also because the operation temperature of the oxidation catalyst is below its optimum range (Schifter et al., 2010). The legislative VOC emissions have been reduced by a factor of 3-4 from the EURO2 to EURO5 legislative limits. The composition of gasoline exhaust (for example $\mathrm{VOC} / \mathrm{NO}_{\mathrm{x}}$ ratio) varies strongly between gasoline vehicles within the same emission class (Clairotte et al., 2013). The emissions from passenger gasoline vehicles may also contain ammonia which is formed as a reaction product when NO is reduced on catalytic surfaces in catalytic converters (Heeb et al., 2006; Kean et al., 2009). Gasoline exhaust contains a complex mixture of VOCs, nitrogen oxides $\left(\mathrm{NO}_{\mathrm{x}}\right)$, ammonia and particulate matter (PM) emissions. However, primary PM emissions are typically lower than for diesel exhaust.

There is currently a debate of the relative proportions of gasoline and diesel exhaust SOA production in the atmosphere. In a recent study in the Los Angeles basin in California, Bahreini et al. (2012) noted that diesel consumption was roughly halved on weekends, and they found a corresponding reduction in primary organic aerosol (POA) and $\mathrm{NO}_{\mathrm{x}}$ but no decrease in SOA that originated from fossil fuel combustion. They concluded that gasoline exhaust is the main source of fossil SOA in the Los Angeles basin. This suggests that diesel exhaust may dominate the emissions of soot particles in urban areas and gasoline exhaust may dominate the SOA formation. However, Gentner et al. (2012) characterized the organic aerosol formation potential of emissions from diesel and gasoline vehicles based on the fuel composition. They concluded that diesel vehicles are responsible for the majority of vehicle SOA but recognized both sources as important. Thus there is a need for more studies especially on the gasoline SOA composition and production rates. Gaso- line SOA may also be an important contributor to the early stages of atmospheric transformation of diesel soot. Aging of soot agglomerates strongly alters the optical and hygroscopic properties of soot particles (Zhang et al., 2008; Pagels et al., 2009a).

Odum et al. (1997) investigated the SOA formation from vaporized gasoline and a large number of light aromatic hydrocarbons occurring in reformulated gasoline. They showed that the SOA formation from vaporized whole gasoline can be well approximated by the sum of the SOA formed from the single light aromatic precursors, but it should be mentioned that the aerosol mass loadings in the study by Odum et al. (2007) were very high compared to other studies (including ours), which affects the partitioning between the particle and gas phase. However, the composition of real-world gasoline exhaust differs from that of vaporized gasoline. For example, the fraction of light aromatics was found to be $21 \%$ by mass in vaporized uncombusted gasoline and $13 \%$ by mass in gasoline exhaust (Schauer et al., 2002). Important classes of compounds with relevance for SOA formation present in gasoline exhaust but not in vaporized gasoline are aldehydes and the complex unresolved mixture of IVOCs not quantified with the gas chromatography - mass spectrometry (GC-MS) techniques typically used (Schauer et al., 2002). Finally, benzene and naphthalene are enriched in the exhaust relative to the fuel (Elghawi et al., 2010).

Kleindienst et al. (2002) performed smog chamber experiments using a gasoline exhaust surrogate mixture made from gasoline fuel and organic additives relevant for the gasoline exhaust. From filter-based techniques they concluded that $75-85 \%$ of the SOA could be explained by $\mathrm{C}_{6}-\mathrm{C}_{9}$ light aromatic compounds and suggested that the remaining fraction was due to higher-order aromatics and cyclic and long-chain alkenes.

There is a need for investigations of the role of $\mathrm{C}_{6}-\mathrm{C}_{9}$ light aromatics and additional precursors in the formation of gasoline SOA in real-world vehicles, particularly in the early aging of gasoline exhaust where IVOCs may be of importance, as has been found for diesel generators (Weitkamp et al., 2007) and wood smoke (Grieshop et al., 2009). There is also a need to define source signatures of gasoline SOA, for example in terms of high-resolution aerosol mass spectra, that can be used for source apportionment studies in ambient air.

In this study, SOA formation of gasoline exhaust emissions from in-use Euro 2, Euro 3 and Euro 4 passenger vehicles was investigated in a smog chamber setup. The aim of this study was (1) to determine the fraction of the SOA from gasoline exhaust that can be explained by classical $\mathrm{C}_{6}-\mathrm{C}_{9}$ light aromatic precursors and (2) to investigate whether the chemical composition of the secondary aerosol from gasoline vehicle exhaust can be simulated using only light aromatic precursors. Better understanding of the magnitude and chemical composition of SOA from anthropogenic sources, like gasoline vehicles, will give valuable information to climate 
modelers and also improve the knowledge of health risks that are linked with air pollution in and downwind of urban environments.

\section{Methods}

\subsection{Experimental setup}

The photo-oxidation experiments were carried out in a $6 \mathrm{~m}^{3}$ $(\mathrm{W} \times \mathrm{L} \times \mathrm{H}, 2.1 \times 1.5 \times 1.8 \mathrm{~m})$ DuPont fluorinated ethylene propylene (FEP) Teflon chamber (Welch Fluorocarbon, USA), with a wall thickness of $125 \mu \mathrm{m}$; a smog chamber setup of similar size is presented in Miracolo et al. (2011). For sampling and air exchange three of the vertical sides were each equipped with three $1 / 4$ " and one $3 / 4$ " Kynar fittings. The Teflon chamber was suspended inside a $22 \mathrm{~m}^{3}$ air-conditioned steel chamber. The steel chamber has been described previously by Pagels et al. (2009b).

Four banks positioned on opposite sides of the smog chamber, each consisting of five $100 \mathrm{~W}$ fluorescent blacklights (Cleo performance 100-R, Phillips, the Netherlands) were used to simulate the spectrum of the UV band in solar irradiation. The light spectrum ranged from $320 \mathrm{~nm}$ to $380 \mathrm{~nm}$, peaking at about $350 \mathrm{~nm}$, which is similar to spectra from several other smog chamber setups (Carter et al., 2005; Presto et al., 2005). The UV spectrum is shown in Fig. S1 in the Supplement. The transmission of FEP at wavelengths between 290 and $800 \mathrm{~nm}$ has been reported to be more than $90 \%$ (Paulsen et al., 2005). To enhance the radiation uniformity and intensity in the chamber, the walls of the enclosing steel chamber were coated with reflective aluminum foil. The $\mathrm{NO}_{2}$ photolysis rate during these experiments was determined to $0.2 \mathrm{~min}^{-1}$, by irradiating a mixture of $\mathrm{NO}_{2}$ and $\mathrm{O}_{3}$.

The temperature inside the steel chamber was controlled by a water-based cooling unit (model 602D $9.43 \mathrm{~kW}$, CIAT, France). This unit gave the means to control the temperature at $22^{\circ} \mathrm{C}$ with a stability of $\pm 2{ }^{\circ} \mathrm{C}$. The temperature was monitored at the midpoint of the Teflon chamber as well as in the space between the smog chamber and the outer steel chamber. A schematic representation of the smog chamber setup and inlet system is shown in Fig. 1.

Gasoline exhaust was injected to the smog chamber through a heated inlet system using an ejector diluter (DI1000, Dekati Ltd, Finland) with an inlet nozzle modified to achieve a primary dilution ratio of $1: 4-5$. The ejector was supplied with pressurized air that was preheated to $140{ }^{\circ} \mathrm{C}$ and filtered by gas-absorbing $\left(\mathrm{NO}_{\mathrm{x}}, \mathrm{SO}_{\mathrm{x}}, \mathrm{O}_{3}\right.$, organic acids) pellets (Triple blend makeup air media, Purafil, USA) and multiple sets of activated carbon and nano particle filters (CLEARPOINT, Beko, Germany). This filter configuration was used for all pressurized air applications to the chamber. The heated exhaust inlet system and cleaning and condition-

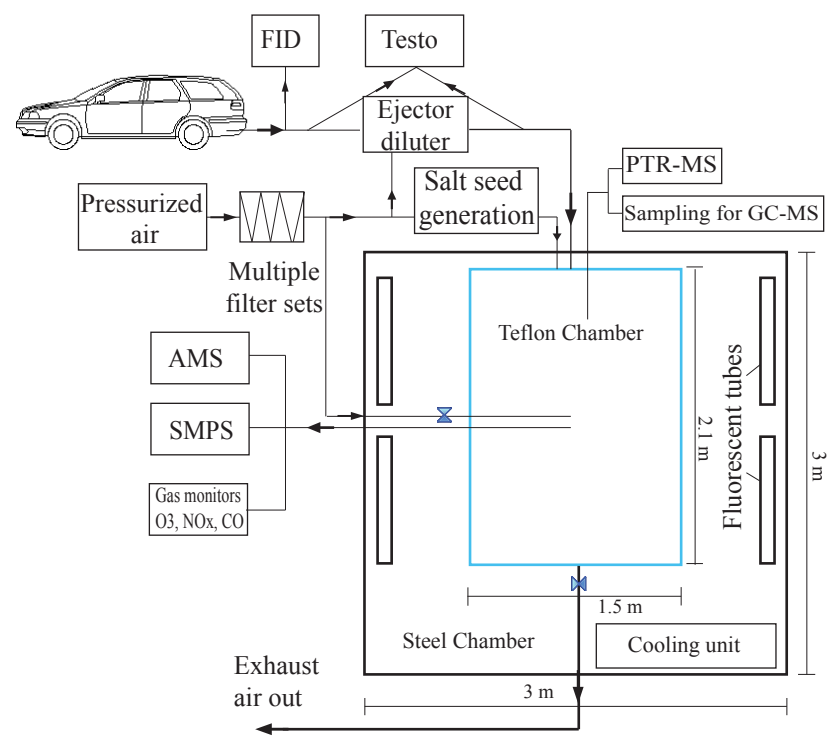

Fig. 1. Schematic representation of the smog chamber and dilution system, seen from above.

ing of the smog chamber are further described in the Supplement.

Before each experiment the particle number concentration was $<100 \mathrm{~cm}^{-3}$ and the particle volume concentration was $<0.1 \mu \mathrm{m}^{3} \mathrm{~cm}^{-3}$. Blank UV exposure experiments, where filtered air was passed through the heated inlet with no exhaust or precursors added to the chamber, were performed to make sure that the cleaning procedure worked properly. The formation of secondary organic aerosol was $<0.1 \mu \mathrm{g} \mathrm{m}^{-3}$ and the formation of nitrate $<0.01 \mu \mathrm{g} \mathrm{m}^{-3}$ during a typical $2 \mathrm{~h}$ blank experiment.

The pressure difference between the inside of the smog chamber and the surrounding steel chamber was monitored by a differential pressure sensor (ASP1400, Sensirion, Switzerland), to ensure that an overpressure was maintained and leaks into the chamber were avoided. The scanning mobility particle sizer (SMPS) data, $\mathrm{NO}, \mathrm{NO}_{2}, \mathrm{O}_{3}, \mathrm{CO}$, chamber $\mathrm{RH}$, temperature and differential pressure were logged using a custom-made LabVIEWTM(National Instruments, USA) program.

\subsection{Vehicles}

Three gasoline-powered passenger vehicles were used in this study, one Euro 2, one Euro 3 and one Euro 4 vehicle (see Supplement Table S1 for more information about the vehicles). All vehicles were driven in normal use in between the experiments. The vehicles were fueled with Swedish standard MK1 gasoline fuel with an octane rating of 95 ("sulfur free" $<10 \mathrm{mg} \mathrm{kg}^{-1}$ ), which complies with latest EU standard (EN 228). The fuel composition was analyzed with GC-MS in a similar way as the exhaust VOC samples as described in Sect. 2.3.3. The mass fraction of $\mathrm{C}_{6}-\mathrm{C}_{9}$ light aromatics was 
$30 \%$. The major oxidative additives used in this fuel were ethanol ( $5 \%$ by volume) and MTBE ( $1.2 \%$ by weight). The result of the fuel analysis is given in Table S3.

\subsection{Instrumentation}

\subsubsection{Particle characterization instruments}

A custom-built SMPS system (Löndahl et al., 2008), consisting of a Vienna-type $\left(\mathrm{L}=0.28 \mathrm{~m}, \mathrm{R}_{1}=0.025 \mathrm{~m}\right.$, $\mathrm{R}_{2}=0.0335 \mathrm{~m}$ ) differential mobility analyzer (DMA) and a condensation particle counter (CPC model 3010, TSI Inc., USA), was used to monitor the size-resolved number concentrations. A sheath flow/aerosol flow relationship of $4.9 / 0.7 \mathrm{~d} \mathrm{~m}^{3} \mathrm{~min}^{-1}$ was used for the measurements, and the used size range was 10 to $600 \mathrm{~nm}$. The particle volume concentration determined from the SMPS data was used as the volume standard and as a reference value for determination of the collection efficiency of the aerosol mass spectrometry (AMS) data. The SMPS and AMS were size calibrated with polystyrene latex (PSL) spheres $(80,100,240$ and $350 \mathrm{~nm}$, Duke Scientific Corp., USA) during the campaign.

The particle chemical composition was measured online by means of a high-resolution time-of-flight aerosol mass spectrometer (HR-ToF-AMS, Aerodyne research Inc., USA). The instrument was equipped with a laser vaporizer to allow detection of refractory black carbon (rBC; soot), a configuration known as the Soot-Particle Aerosol Mass Spectrometer (SP-AMS). The HR-ToF-AMS and SP-AMS are described in detail elsewhere (DeCarlo et al., 2006; Onasch et al., 2012) and briefly below. The aerosol is sampled through an aerodynamic lens, which focuses sub-micrometer particles into a tight beam. The particle beam is modulated to obtain particlesize-resolved information using the particle time-of-flight (PToF) mode. After impaction on a heated $\left(600^{\circ} \mathrm{C}\right)$ tungsten vaporizer plate, under low pressure $(\sim 10 \mu \mathrm{Pa})$, the operationally defined non-refractory particulate mass (NR-PM) is vaporized and ionized using electron ionization $(70 \mathrm{eV})$. The ions are subsequently analyzed through time-of-flight mass spectrometry. In these experiments NR-PM is expected to include all PM components except rBC. The instrument was operated in dual vaporizer mode, i.e., both laser and tungsten vaporizers were present. The laser vaporizer was turned on in 5 min periods every hour in most experiments, in order to probe $\mathrm{rBC}$ without interfering significantly with the tungsten vaporizer data set. Data analysis was performed with IGOR pro 6 (Wavemetrics, USA), SQUIRREL 1.51 and PIKA 1.1. Elemental analysis (EA) was performed on V-mode data. The fragmentation pattern and calibration factors suggested by Aiken et al. (2008) were used. Nitrate fragments were excluded from the elemental analysis. Gas-phase contributions (e.g., $\mathrm{CO}_{2}^{+}$) to the detected signals were subtracted using filtered air measurements carried out in 5 min periods several times in each experiment.

\subsubsection{Measurement of inorganic gases}

The $\mathrm{O}_{3}$ concentration was monitored using a UV spectrophotometer (model 49i ozone analyzer, Thermo Scientific, USA). The $\mathrm{NO}$ and $\mathrm{NO}_{2}\left(\mathrm{NO}_{\mathrm{y}}-\mathrm{NO}\right)$ concentrations were monitored by a $\mathrm{NO}_{\mathrm{x}}$ monitor (model CLD $700 \mathrm{AL}$, Eco Physics, USA). The $\mathrm{NO}_{\mathrm{x}}$ instrument uses two measurement chambers which gives a direct measurement of $\mathrm{NO}$ and an indirect $\mathrm{NO}_{2}$ measurement. The principle for measurement of $\mathrm{NO}_{2}$ is converting $\mathrm{NO}_{2}$ to $\mathrm{NO}$ by a molybdenum converter at high temperature $\left(375^{\circ} \mathrm{C}\right)$; the converter also converts peroxy acyl nitrates (PAN), $\mathrm{HONO}$ and nitric acid $\left(\mathrm{HNO}_{3}\right)$ to NO. This gives an interference of the $\mathrm{NO}_{2}$ signal (Gerboles et al., 2003). The monitoring of $\mathrm{O}_{3}$ and $\mathrm{NO}_{\mathrm{x}}$ was continuous throughout the experiment.

$\mathrm{CO}, \mathrm{NO}_{\mathrm{x}}$ and $\mathrm{O}_{2}$ were measured in the raw exhaust by a gas analyzer (model $350 \mathrm{XL}$, Testo, Germany) in selected experiments. The $\mathrm{CO}$ mixing ratio in the smog chamber was typically below $1 \mathrm{ppm}$ for the idling experiments and about $8 \mathrm{ppm}$ in the cold start experiment.

\subsubsection{Measurement of organic gas-phase compounds}

The concentration of light aromatic compounds and other selected VOCs were monitored using a proton transfer reaction mass spectrometer (PTR-MS, Ionicon Analytik GmbH, Austria), which allows real-time measurements of concentrations down to the ppt range. Since the quadrupole version of the PTR-MS instrument measures only with a unity resolution, different compounds with the same nominal mass cannot be distinguished. A detailed description of the PTR-MS technique is given by Lindinger et al. (1998) and de Gouw and Warneke (2007). The used volume mixing ratio calculations and calibration procedures are described by Taipale et al. (2008).

VOC samples were collected on adsorbent tubes filled with Tenax-TA and Carbopack-B and were analyzed in the laboratory with GC-MS, using a thermal desorption instrument (Perkin-Elmer TurboMatrix 650, Waltham, USA) attached to a gas chromatograph (Perkin-Elmer Clarus 600, Waltham, USA) with DB-5MS ( $60 \mathrm{~m}, 0.25 \mathrm{~mm}, 1 \mu \mathrm{m})$ column and a mass selective detector (Perkin-Elmer Clarus 600T, Waltham, USA). Typically, duplicate adsorbent tube samples were collected before the UV lights were turned on and at the end of the experiment. Thirteen $\mathrm{C}_{6}-\mathrm{C}_{9}$ light aromatic compounds and selected alkanes were quantified.

GC-MS was the standard method for determining the mass concentration of $\mathrm{C}_{6}-\mathrm{C}_{9}$ light aromatic hydrocarbons. The PTR-MS was available in four experiments (I1, I2, S1 and P1) and was used for monitoring of time-resolved VOC concentrations. The VOC levels showed good agreement between the methods (see Fig. S3 in the Supplement for comparison).

Initial $\mathrm{C}_{10}$ and $\mathrm{C}_{11}$ light aromatics and naphthalene concentrations were estimated from the PTR-MS channels 
$\mathrm{m} / \mathrm{z}$ 135, 149 and 129, respectively, in experiments when the PTR-MS was available; similar measurements have previously been performed by Jobson et al. (2010).

Cumulative $\mathrm{OH}$ radical exposures were estimated to allow investigation of the effect of atmospheric processing on the aerosol MS composition data. The decay curves of $\mathrm{C}_{8}$ and $\mathrm{C}_{9}$ aromatics from PTR-MS and 1,2,4-TMB from GC-MS were fitted using a simple model to derive the $\mathrm{OH}$ concentration as a function of time. In the case of using the PTR-MS data, average $\mathrm{OH}$ reactivities based on the speciated GC-MS data were used. $\mathrm{OH}$ exposures were typically within $15 \%$ when comparing analyses based on $\mathrm{C}_{8}$ and $\mathrm{C}_{9}$ aromatics.

\subsection{Experimental procedure}

Before the experiments the smog chamber was filled with clean dry pressurized air (relative humidity 3-5\%). A nebulized water (Pro Analysi, Merck, Germany) solution of ammonium sulfate $\left(1 \mathrm{~g} \mathrm{dm}^{-3}\right)$ (Merck, Germany) was utilized as condensation seeds to collect the formed low vapor pressure reaction products. The nebulizer (Collison type, Topas Gmbh, Germany) was operated by filtered pressurized air ( 3 bar). The aerosol particles were dried using a silica diffusion drier and passed through a ${ }^{63} \mathrm{Ni}$ bipolar charger before being introduced to the smog chamber. The salt seeds were injected for about 20-30 min until a concentration of $15-20 \mu \mathrm{g} \mathrm{m}^{-3}$ was accomplished, corresponding to an initial number concentration of 20000-25000 particles $\mathrm{cm}^{-3}$.

Two different idling cases were defined: (1) cold start: the vehicle was started on site (after cold soaking for $>3 \mathrm{~h}$ ) and the exhaust was injected to the smog chamber from first ignition; and (2) idling: the vehicles were driven for about $3 \mathrm{~min}$ before injection, until an engine temperature of $55 \pm 5{ }^{\circ} \mathrm{C}$ (Euro 2) was established. The ambient temperature was between -5 and $+3{ }^{\circ} \mathrm{C}$ during the campaign (Table S2 in the Supplement).

In the precursor experiments, m-xylene or a mixture of three selected precursors was injected through evaporation from a glass flask purged with pressurized air. The precursors used were toluene ( $>99.5 \%$ Merck, Germany), m-xylene (>99\%, Sigma-Aldrich, USA) and 1,2,4-trimethylbenzene (>98\%, Alfa Aesar, Germany). 1,2,4-trimethylbenzene was chosen because it is often the most abundant $\mathrm{C}_{9}$ aromatic in idling gasoline exhaust (Table S3 in the Supplement and Schauer et al., 2002).

The target VOC concentration in the chamber for each gasoline exhaust experiment was established using PTR-MS (raw spectrum intensities of $m / z$ 93, 107, 121) sampling from the smog chamber and a flame ionization detector (FID, Model RS 53-T, Ratfisch, Germany), with a sampling line heated to $100^{\circ} \mathrm{C}$, sampling from the raw exhaust. The total VOC concentration in the chamber (FID) was between 1 and $2.5 \mathrm{ppm}$ in the gasoline exhaust experiments. The length of the exhaust injection period was typically $5-15 \mathrm{~min}$ for idling and $60 \mathrm{~s}$ for cold start. Including the dilution in the Teflon chamber, a total dilution ratio for the idling experiments of 30-120 was achieved, depending on the injection time of the exhaust. Additional NO typically had to be added after the exhaust injection to achieve a desired ratio between light aromatics (LA) and $\mathrm{NO}_{\mathrm{x}}\left(\mathrm{ppbC} \mathrm{ppb}^{-1}\right)$. In four gasoline exhaust experiments and the two precursor experiments (Table 2), a light aromatic-to- $\mathrm{NO}_{\mathrm{x}}$ ratio of around $50 \mathrm{ppbC} \mathrm{ppb}^{-1}$ was used. In experiments $\mathrm{I} 3$ and $\mathrm{I} 4$, lower $\mathrm{LA}$-to- $\mathrm{NO}_{\mathrm{x}}$ ratios of 13 and 7, respectively, were used. In experiment $\mathrm{I} 4, \mathrm{O}_{3}$ was added to convert a major fraction of the emitted NO into $\mathrm{NO}_{2}$. The level of $\mathrm{NO}$ at the start of the experiments was 35-107 ppb. $\mathrm{O}_{3}$ was produced by a modified spark discharge ozone generator (AM 3000-2, Ozone Technology, Sweden), using pure $\mathrm{O}_{2}$ (medical grade, Air Liquid).

After exhaust injection and addition of $\mathrm{NO}$ or $\mathrm{O}_{3}$, there was a period of 30 to $60 \mathrm{~min}$ to allow mixing in the chamber and for characterization of the fresh exhaust composition. After this the UV lights were lit, which is referred to as time $t=0$ throughout the paper. The length of the experiments was $3-4 \mathrm{~h}$.

\subsection{Data analysis}

\subsubsection{Wall loss corrections}

Aerosol particles suspended in a Teflon chamber may deposit to the chamber walls (McMurry and Rader, 1985), due to electrostatic forces and other deposition mechanisms, such as sedimentation and diffusion. To be able to quantify the SOA formation, wall losses have to be accounted for. In this work, a wall loss correction method based on AMS data was used (Hildebrandt et al., 2009). An assumption is made that VOCs do not condense on the chamber walls but are rather in equilibrium with particles deposited on the walls. The particulate sulfate seed is then conserved by the chamber system. The wall-loss-corrected organic aerosol mass concentration $\left(C_{\mathrm{OA}}(t)\right)$ as a function of time is calculated by Eq. (1), by multiplying the mass concentration of seed aerosol at the time when UV light was initiated $\left(C_{\text {seed }}^{\text {sus }}(t=0)\right)$ with the ratio between organic aerosol $\left(C_{\mathrm{OA}}^{\text {sus }}(t)\right)$ and ammonium sulfate seed concentrations $\left(C_{\text {seed }}^{\text {sus }}(t)\right)$ derived from AMS data. $C_{\text {seed }}^{\text {sus }}(t=0)$ is derived from SMPS measurements, using a $\rho_{\text {seed }}$ of $1,769 \mathrm{~g} \mathrm{~cm}^{-3}$. For ammonium nitrate and SOA we used densities of $1.72 \mathrm{~g} \mathrm{~cm}^{-3}$ and $1.40 \mathrm{~g} \mathrm{~cm}^{-3}$, respectively.

$C_{\mathrm{OA}}(t)=\frac{C_{\mathrm{OA}}^{\mathrm{sus}}(t)}{C_{\mathrm{seed}}^{\mathrm{sus}}(t)} C_{\mathrm{seed}}^{\mathrm{sus}}(t=0)$

This method also accounts for an increase in collection efficiency (CE) of the AMS, most likely due to decreased bounce when the seed particles become coated with SOA. A typical change in CE was from 0.25 for ammonium sulfate before exhaust to 0.4 at the end of the experiment. AMS and SMPS size distributions at the beginning and end of experiment $\mathrm{I} 2$ are given in Fig. S4. It should be pointed out 
that uncertainties originating from wall loss correction are likely small when comparing the experiments reported here to each other. But there may be larger uncertainties when extrapolating our results to other chambers and experimental conditions. Clearly wall loss correction methods merit further investigation. Secondary sulfates may also form in the chamber from oxidation of $\mathrm{SO}_{2}$; however, the sulfur content of European gasoline fuel is extremely low $(<10 \mathrm{ppm})$. To make sure that secondary sulfates did not bias the measurements, we carried out several nucleation experiments with gasoline exhaust under conditions similar to the seeded experiments. It was found that secondary sulfate formation was $0.1-0.3 \mu \mathrm{g} \mathrm{m}^{-3}$. The resulting influence of the wall-losscorrected SOA concentration is therefore less than $5 \% \mathrm{in} \mathrm{ev-}$ ery experiment.

The half-life of ammonium sulfate particles by mass in experiments with no or negligible SOA formation was found to be $\sim 3 \mathrm{~h}$ for the period starting when the UV lights were turned on, which makes quantitative experiments meaningful up to about $4 \mathrm{~h}$ after $\mathrm{UV}$ has been turned on.

\subsubsection{Aerosol mass yield}

The aerosol mass yield $Y$ at time $t$ is defined as the ratio between the wall-loss-corrected formed organic mass concentration divided by the mass concentration of reacted VOCs $(\Delta \mathrm{HC}$ ), at time $t$ (Eq. 2) (Odum et al., 1997).

$Y=\frac{C_{\mathrm{SOA}}}{\Delta \mathrm{HC}}$

In the calculations presented in this paper $t$ exclusively refers to the end of the experiment. For the gasoline experiments an apparent mass yield was calculated taking into account only $\mathrm{C}_{6}-\mathrm{C}_{9}$ alkyl-substituted light aromatics and benzene; thus the $\triangle \mathrm{HC}$ term only consists of these compounds. $\Delta \mathrm{HC}$ is the difference in light aromatics before and after an experiment measured by GC-MS. These apparent mass yields can then be compared with true mass yields from the pure precursor experiments carried out under similar conditions in our chamber, to gain insight into the fraction of formed SOA that originated from $\mathrm{C}_{6}-\mathrm{C}_{9}$ light aromatics.

\subsubsection{Primary exhaust particles and subtraction of primary organic aerosol}

Upon exhaust injection an immediate increase in OA was observed in each experiment, after which a plateau was reached. This fraction of OA is referred to as primary organic aerosol (POA). The ratio of POA to sulfate seed and the POA composition were assumed to be constant throughout the experiments. The POA/sulfate seed ratio is determined during a $5 \mathrm{~min}$ period about $15 \mathrm{~min}$ after exhaust injection to allow the exhaust to mix in the smog chamber. The estimated POA concentration at the end of the experiment was subtracted from the wall-loss-corrected organic concentrations to determine $C_{\mathrm{SOA}}$. When determining the fraction of organic mass for each AMS fragment (e.g., $f_{43}$ ), the POA fraction was deducted using the same assumptions as for whole POA described above. The correction was carried out for experiments I1 and S1, where the POA mass fraction was higher than $5 \%$. The POA and particulate nitrates observed in these experiments will be treated in more detail in future publications.

The primary emissions from the Euro 2 vehicle were investigated in a separate experiment without condensation seeds. The emissions of primary particles were less than 50 particles $\mathrm{cm}^{-3}$ in the smog chamber at a dilution ratio of $1: 36$ for the idling gasoline emissions, indicating that the concentration of primary particles (such as soot cores) were negligible compared to the seed aerosol $(\sim 20000$ $25000 \mathrm{~cm}^{-3}$ ). Only in the cold start experiment (S1) was there a noticeable increase in the number concentration (about $2000 \mathrm{~cm}^{-3}$ ) upon adding the exhaust to the chamber. Similarly, only in the cold start experiment was there a noticeable signal of $\mathrm{rBC}$ detected with the SP-AMS. The mass concentration of $\mathrm{rBC}$ was estimated to be $1.5 \mu \mathrm{g} \mathrm{m}^{-3}$ and $<0.3 \mu \mathrm{g} \mathrm{m}^{-3}$ in the cold start and idling experiments, respectively.

\section{Results and discussion}

A summary of the results and conditions from six gasoline exhaust experiments and two precursor experiments is presented in Table 2. Photo-oxidation of gasoline exhaust forms SOA and ammonium nitrate. At the end of the experiments the formed SOA is 9-500 times higher than the emitted POA, which is in sharp contrast to diesel exhaust where the contribution of primary PM often dominates over secondary PM (Chirico et al., 2010). Experiment I1 had the highest contribution of POA, corresponding to $12 \%$ of the OA in the chamber at the end of the photo-oxidation experiment, while in experiments I 2 and $\mathrm{I} 3$ the POA contribution was less than $0.5 \%$. The POA most likely originates from organic compounds with volatility low enough to condense onto the seed particles when the exhaust is cooled down after injection in the smog chamber. The aerosol mass spectra of these primary emissions were similar to diesel exhaust POA and the hydrocarbon-like organic aerosol (HOA) found in urban areas.

\subsection{VOC composition and emissions}

The classical light aromatic precursors $\left(\mathrm{C}_{6}-\mathrm{C}_{9}\right)$ constituted $30 \%$ of the fuel by mass but only $10-15 \%$ of the total VOC emissions in the gasoline exhaust, where the latter figure includes methane (Table 1).

In Fig. 2 it is shown that the distribution of light aromatic SOA precursors depends on both vehicle type and operation mode. In the cold start with the Euro 4 vehicle, the distribution of the light aromatics is similar to the distribution in 
Table 1. Initial experimental conditions.

\begin{tabular}{|c|c|c|c|c|c|c|c|}
\hline Exp-ID & Type & Source & $\begin{array}{l}\text { Initial } \mathrm{C}_{6}-\mathrm{C}_{9} \\
\text { light aromatics } \\
(\mathrm{ppb})\end{array}$ & $\begin{array}{l}\text { Initial NO } \\
(\mathrm{ppb})\end{array}$ & $\begin{array}{l}\text { Initial }\left(\mathrm{NH}_{4}\right)_{2} \mathrm{SO}_{4} \\
\left(\mu \mathrm{g} \mathrm{m}^{-3}\right)\end{array}$ & $\begin{array}{l}\text { Total } \\
\text { hydrocarbons }{ }^{\mathrm{a}} \\
(\mathrm{ppm})\end{array}$ & $\begin{array}{l}\text { Relative } \\
\text { humidity }(\%)^{\mathrm{b}}\end{array}$ \\
\hline I1 & Idling & Euro 2 & 303 & 33 & 10 & 2.4 & 10 \\
\hline $\mathrm{I} 2$ & Idling & Euro 2 & 317 & 47 & 18 & 2.5 & 7 \\
\hline I3 & Idling & Euro 2 & 197 & 107 & 13 & 2.2 & 7 \\
\hline I4 & Idling & Euro 3 & 123 & $20^{\mathrm{c}}$ & 15 & 1.0 & 8 \\
\hline I5 & Idling & Euro 4 & 289 & 35 & 22 & 2.2 & 7 \\
\hline S1 & Cold start & Euro 4 & 402 & 47 & 6 & $\sim 1$ & 3 \\
\hline $\mathrm{P} 1$ & Precursor & tol, m-xyl, 1.2.4-tmb & 288 & 43 & 18 & - & 3 \\
\hline $\mathrm{P} 2$ & Precursor & m-xyl & 250 & 38 & 19 & - & 3 \\
\hline
\end{tabular}

a The total VOC concentration was measured before primary dilution.

b Initial value

c The given $\mathrm{NO}$ value is after addition of $\mathrm{O}_{3}$ to convert $\mathrm{NO}$ to $\mathrm{NO}_{2}$; the initial $\mathrm{NO}$ concentration prior to addition of $\mathrm{O}_{3}$ was 125 ppb.

the fuel. In the cold start experiment it is expected that the VOC emissions may be well represented by vaporized fuel, due to the low temperatures of the engine (Schifter et al., 2010). A more detailed analysis of the light aromatic content in the fuel and gasoline exhaust is presented in Table S3 in the Supplement.

The distribution of light aromatics from the Euro 2 vehicle was fairly repeatable under idling conditions (Fig. 2) and shows an even distribution between the $\mathrm{C}_{6}-\mathrm{C}_{9}$ light aromatics. The Euro 3 and Euro 4 vehicles when used under idling showed a trend towards decreasing concentration with increasing molecular size. The benzene concentration is strongly elevated in these idling experiments compared to the fuel content (benzene is regulated to $<1 \%$ by volume in gasoline in Europe), most likely due to formation of benzene from other light aromatic compounds in the catalyst (Bruehlmann et al., 2007). The enrichment of benzene in the exhaust is also found in road tunnel emission measurements (Legreid et al., 2007). The distribution of light aromatics from the idling case represents the road tunnel data reasonably well.

The concentration of $\mathrm{C}_{10}$ and $\mathrm{C}_{11}$ light aromatics and naphthalene were assessed from the corresponding PTR-MS channels $(m / z=135,149$ and 129). This was done for the Euro 2 vehicle at idling (I1 and I2 experiments) and the cold start experiment (S1) with the Euro 4 vehicle. The contribution in percent to the summed initial mixing ratio (ppb) of $\mathrm{C}_{6}-\mathrm{C}_{11}$ light aromatics and naphthalene was as follows: 4.6, $0.4 \%$ (C10); $0.8,<0.1 \%$ (C11); and $1.1,<0.1 \%$ (naphthalene) for idling (I1 and I2) and cold start, respectively. As shown the $\mathrm{C}_{10}, \mathrm{C}_{11}$ and naphthalene fraction is significantly higher at idling compared to the cold start.

\subsection{Formation of gasoline SOA}

Figure $3 \mathrm{a}$ and $\mathrm{b}$ compare the temporal evolution for one representative gasoline experiment (I2) and an experiment with a precursor mixture $(\mathrm{P} 1)$ containing three of the most im-

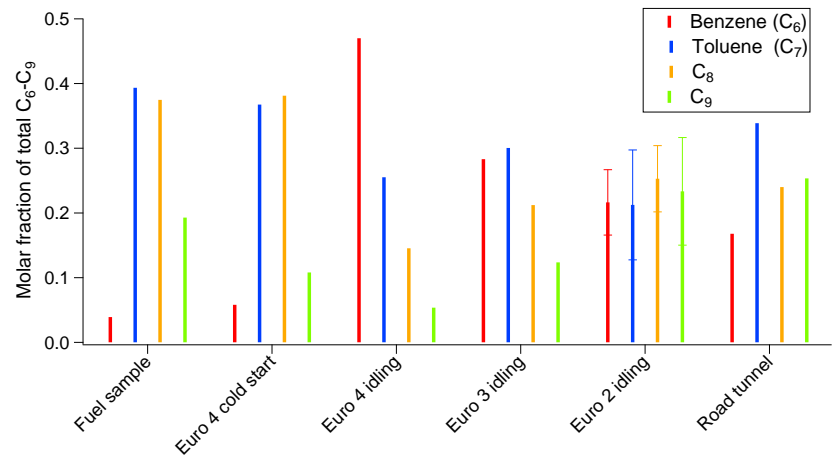

Fig. 2. The molar fraction of $\mathrm{C}_{6}-\mathrm{C}_{9}$ light aromatics (GC-MS) in the exhaust, a sample of the gasoline fuel used in the measurement campaign and VOC measurements in a road tunnel (Legreid et al., 2007). The whiskers indicate \pm 1 standard deviation $(\sigma)$ of repeated measurements. Legreid et al. (2007) only measured 1,2,4-TMB; the total $\mathrm{C}_{9}$ concentration is estimated from that number and the fraction of 1,2,4-TMB of total $\mathrm{C}_{9}$ in our exhaust measurements.

portant $\mathrm{C}_{7}-\mathrm{C}_{9}$ light aromatic precursors. The upper panels show the mixing ratios of $\mathrm{NO}, \mathrm{NO}_{2}$ and $\mathrm{O}_{3}$ (left y-axis) and the ratio of nitrate and $\mathrm{OA}$ to sulfate seed (right y-axis). The middle panels show the mixing ratios for the most important light aromatic precursors and one photochemical gas-phase reaction product, obtained by PTR-MS. The PTR-MS channels correspond to toluene $\left(C_{7} \mathrm{~m} / z=93\right), C_{8}(m / z=107)$, $\mathrm{C}_{9}(m / z=121), \mathrm{C}_{10}(m / z=135)$ aromatics and acetaldehyde $(m / z=45)$. In the P1 experiment (Fig. 3b), toluene, m-xylene $\left(\mathrm{C}_{8}\right)$ and 1,2,4-trimethylbenzene $\left(\mathrm{C}_{9}\right)$ were used as precursors. The lower panels show the $\mathrm{H}: \mathrm{C}$ and $\mathrm{O}: \mathrm{C}$ elemental ratios of the formed SOA, derived from AMS data.

The SOA formation is delayed $30-45 \mathrm{~min}$ after the lights are turned on, corresponding to the time required to initiate photochemistry and for $\mathrm{NO}$ to be converted to $\mathrm{NO}_{2}$ (Fig. 3). The NO-to- $\mathrm{NO}_{2}$ conversion, and thereby the formation of ozone and $\mathrm{HO}_{\mathrm{x}}$, occurs slightly faster in the gasoline exhaust 

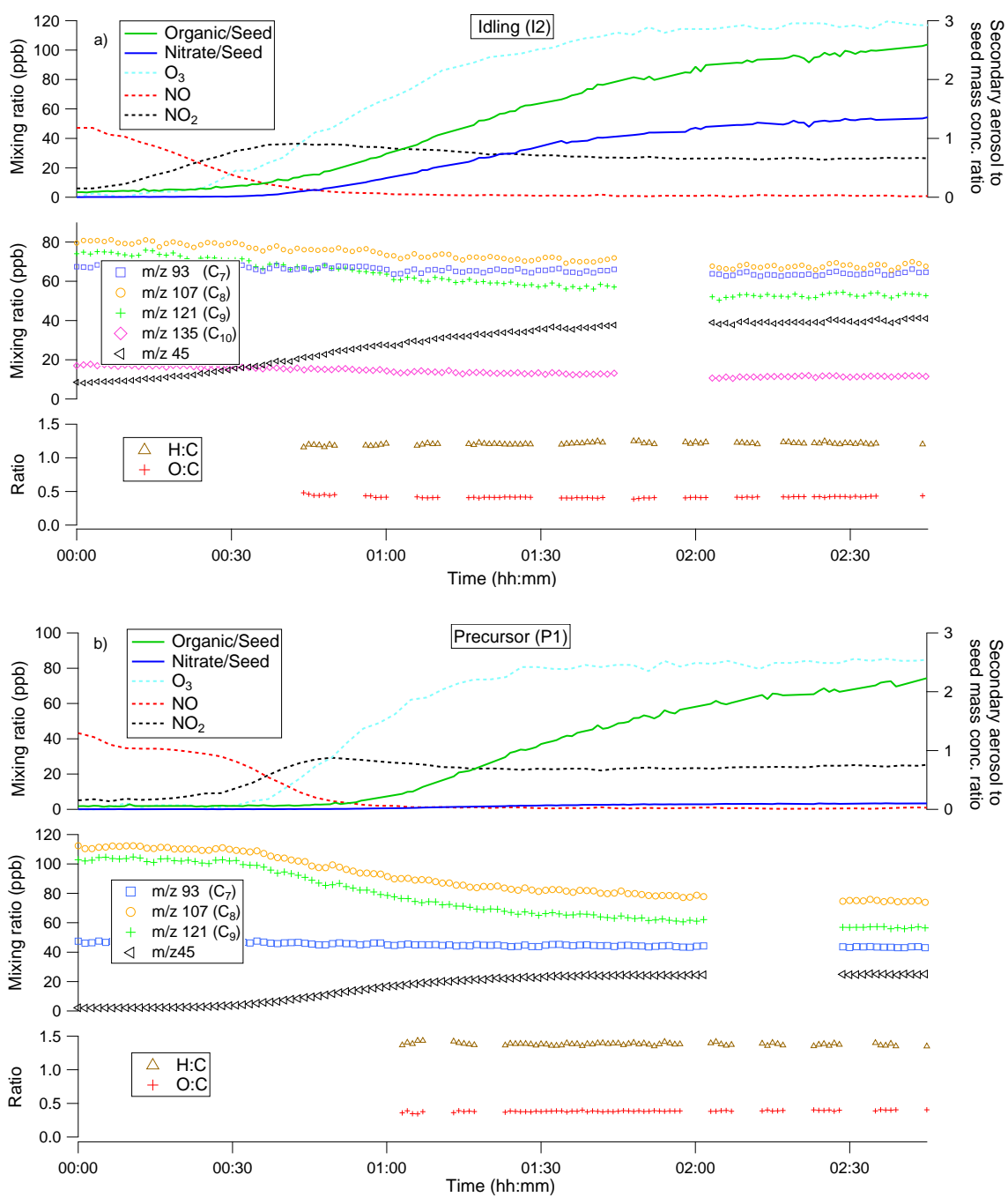

Fig. 3. Time-resolved data from experiments $\mathrm{I} 2$ (a) and $\mathrm{P} 1$ (b). The upper panels show the mixing ratios of $\mathrm{NO}, \mathrm{NO}_{2}$ and $\mathrm{O}_{3}$ (left $\mathrm{y}$-axis) and the mass ratio between SOA, nitrate and seed aerosol on the right $y$-axis. The middle panels represent the mixing ratio of light aromatics ( $m / z$ 93: toluene; $\mathrm{m} / \mathrm{z}$ 107: $\mathrm{C}_{8}$-aromatics; $\mathrm{m} / \mathrm{z}$ 121: $\mathrm{C}_{9}$-aromatics; $\mathrm{m} / \mathrm{z}$ 135: $\mathrm{C}_{10}$-aromatics) and acetaldehyde $(\mathrm{m} / \mathrm{z}$ 45). The lower panels feature the $\mathrm{H}: \mathrm{C}$ and $\mathrm{O}: \mathrm{C}$ ratios extracted from elemental analysis of organic aerosol in high-resolution AMS data. The UV lights were turned on at time $=00: 00$. Missing data points are either due to internal calibration (PTR-MS), thermodenuder measurements (AMS) or omitted on account of low mass loadings.

Table 2. Summary of the results and experimental conditions.

\begin{tabular}{|c|c|c|c|c|c|c|c|}
\hline Exp.-ID & $\begin{array}{l}\text { Initial LA to } \\
\mathrm{NO}_{\mathrm{x}} \text { ratio } \\
\left(\mathrm{ppbC} \mathrm{ppb}^{-1}\right)\end{array}$ & $\begin{array}{l}\text { Formed } \\
\text { ozone } \\
\text { (ppb) }\end{array}$ & $\begin{array}{l}\text { Reacted LA } \\
\left(\mathrm{C}_{6}-\mathrm{C}_{9}\right) \\
\left(\mu \mathrm{g} \mathrm{m}^{-3}\right)\end{array}$ & $\begin{array}{l}\text { Emitted POA } \\
\left(\mu \mathrm{g} \mathrm{m}^{-3}\right)\end{array}$ & $\begin{array}{l}\text { Formed SOA } \\
\left(\mu \mathrm{g} \mathrm{m}^{-3}\right)\end{array}$ & $\begin{array}{l}\text { Apparent mass } \\
\text { yield } Y\end{array}$ & $\begin{array}{l}\text { Formed } \mathrm{NO}_{3} \\
\left(\mu \mathrm{g} \mathrm{m}^{-3}\right)\end{array}$ \\
\hline I1 & 55 & 111 & 138 & 2.9 & 21 & 0.15 & 9 \\
\hline $\mathrm{I} 2$ & 45 & 118 & 198 & 0.2 & 44 & 0.22 & 24 \\
\hline $\mathrm{I} 3$ & 13 & 156 & 264 & 0.1 & 51 & 0.19 & 71 \\
\hline I4 & 7 & 72 & 97 & 0.1 & 9 & 0.09 & 91 \\
\hline I5 & 53 & 102 & 122 & 0.2 & 5 & 0.04 & 4 \\
\hline S1 & 64 & 98 & 205 & 0.6 & 12 & 0.06 & $<1$ \\
\hline $\mathrm{P} 1$ & 49 & 86 & 462 & - & 53 & 0.12 & 2 \\
\hline $\mathrm{P} 2$ & 49 & 72 & 435 & - & 59 & 0.14 & 2 \\
\hline
\end{tabular}




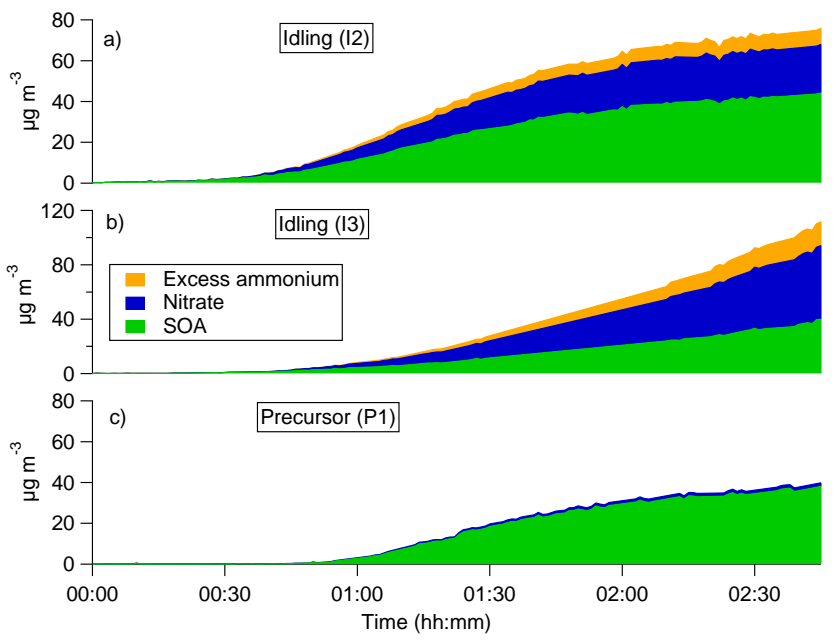

Fig. 4. Chemically resolved wall-loss-corrected mass concentration $\left(\mu \mathrm{g} \mathrm{m}^{-3}\right)$ from AMS data from experiments I2 (a), I3 (b) and P1 (c). The ammonium sulfate seed has been subtracted. The reported ammonia is excess ammonia not bound to sulfate, thus indicative of ammonium nitrate formation. Time $=00: 00$ indicates the start of the UV radiation. As an example for experiment I3, the nonwall-loss-corrected SOA concentration at the end of the experiment was $25 \mu \mathrm{g} \mathrm{m}^{-3}$ and the wall-loss-corrected concentration was $51 \mu \mathrm{g} \mathrm{m}^{-3}$.

experiment compared to the pure precursor experiment. The delay between ozone and SOA formation is shorter and the SOA formation starts at a higher NO level in the idling gasoline exhaust experiment compared to the precursor experiment. These differences are attributed to the large group of additional VOCs (in addition to $\mathrm{C}_{6}-\mathrm{C}_{9}$ light aromatics) present in the gasoline exhaust compared to the pure precursor experiment.

The initial concentrations of $\mathrm{C}_{7}-\mathrm{C}_{9}$ aromatics are all at a similar level in the idling gasoline exhaust, while the $\mathrm{C}_{10}$ aromatics are present in much lower concentrations. The reactivity typically increases with increasing carbon number. For example m-xylene and 1,2,4-trimethylbenzene are much more reactive than toluene. The sum of the concentration of reacted light aromatics $\left(\mathrm{C}_{6}-\mathrm{C}_{9}\right)$ is used for mass yield calculations, although the reacted fraction of benzene is small under the prevailing (atmospherically relevant) $\mathrm{OH}$ radical concentrations $\left(1-3 \times 10^{6} \mathrm{~cm}^{-3}\right)$, due to its low reactivity with the $\mathrm{OH}$ radical.

The $\mathrm{O}: \mathrm{C}$ and $\mathrm{H}: \mathrm{C}$ ratios were both similar for the gasoline exhaust and the precursor experiment $(\sim 0.4$ and $\sim 1.4$, respectively), throughout the experiments. Figure 4 shows the wall-loss-corrected mass concentration of SOA, nitrate and excess ammonium for experiments I2 (a), I3 (b) and P1 (c); the ammonium sulfate seed mass has been subtracted. The reacted mass concentrations of $\mathrm{C}_{6}-\mathrm{C}_{9}$ light aromatics were about two times higher for the precursor experiment compared to the gasoline exhaust experiments. Still,

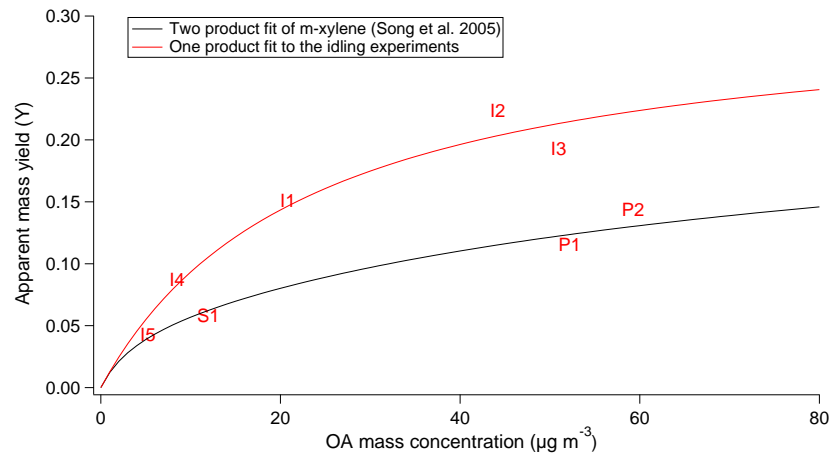

Fig. 5. The apparent mass yield (Eq. 2) from the gasoline experiments plotted against the concentration of organic aerosol mass. The red line represents a one product fit, $\left(Y=C_{\mathrm{OA}}\left(a_{1} \cdot k_{1} /\left(1+k_{1}\right.\right.\right.$. $\left.C_{\mathrm{OA}}\right)$, where $a_{1}=0.311$ and $k_{1}=0.043$ ) to the apparent mass yield for experiments I1-I5. The black line is a two product fit to the $\mathrm{m}$ xylene yield from Song et al. (2005), (scaled by 0.88 and assuming a density of $1.4 \mathrm{~g} \mathrm{~cm}^{-3}$ ) to fit the precursor experiments carried out in this study. I1-I5 represents idling, S1 cold start and P1-P2 the precursor experiments.

the wall-loss-corrected SOA mass concentration was similar (Table 2).

Formation of nitrate occurs only to a limited extent in the precursor experiments (about $4 \%$ of the total organics). The nitrate formation in the precursor experiment is attributed to formation of particle-phase organic nitrates, while the formation of nitrate in the gasoline experiments can be attributed to a mixture of ammonium nitrate and organic nitrates that varies strongly between experiments. Information on the occurrence of organic and ammonium nitrate can be obtained from the $\mathrm{NO}^{+} / \mathrm{NO}_{2}^{+}$ion fragment ratio in the AMS. The $\mathrm{NO}^{+} / \mathrm{NO}_{2}^{+}$ratio is substantially higher for SOA from light aromatic precursors compared to ammonium nitrate (Sato et al., 2010). This analysis will be reported separately.

The ammonium nitrate is most likely formed by reactions of ammonia from the car exhaust and $\mathrm{HNO}_{3}$ formed by reactions in the smog chamber (originating from $\mathrm{NO}_{\mathrm{x}}$ ). SOA from passenger vehicle emissions co-condenses with ammonia and nitric acid as can be expected during atmospheric processing of pollutants. The ammonium nitrate formation increased with increasing initial $\mathrm{NO}_{\mathrm{x}}$ level, and thus in experiment $\mathrm{I} 3$ the aerosol was dominated by nitrate.

\subsection{SOA mass yield of gasoline exhaust and precursors}

The apparent mass yield, $Y$, is defined here as the ratio between the mass concentration of formed secondary organic aerosol, $C_{\mathrm{SOA}}$, and the mass concentration of reacted light aromatic compounds $\left(\mathrm{C}_{6}-\mathrm{C}_{9}\right), \Delta \mathrm{HC}$ (Eq. 2). By comparing the apparent mass yields with the yields from the precursor experiments at a given $C_{\mathrm{SOA}}$, we can infer the contribution from additional SOA precursors. The apparent mass yield from $\mathrm{C}_{6}-\mathrm{C}_{9}$ light aromatics in the gasoline exhaust SOA 
increases with increasing concentration of organic aerosol in the smog chamber, as has been shown in several previous studies for yields of single precursor systems (Cocker et al., 2001; Song et al., 2005; Ng et al., 2007; Hildebrandt et al., 2009). A one-product fit (Odum et al., 1997) to the idling data is shown in Fig. 5.

Our precursor data agree well with m-xylene data from Song et al. (2005) carried out under similar conditions (socalled classical photo-oxidation experiments); therefore we used their fit to extend the comparison between our precursor and gasoline exhaust data towards lower mass concentrations. The mass yield for experiments $\mathrm{P} 1$ and $\mathrm{P} 2$ is $2-3$ times lower than some pure precursor experiments presented in the literature (Hildebrandt et al., 2009; $\mathrm{Ng}$ et al., 2007). Those experiments with significantly higher yield have been performed using $\mathrm{H}_{2} \mathrm{O}_{2}$ as $\mathrm{OH}$ precursor. The experiments presented in this paper were performed without added $\mathrm{OH}$ precursors. In the beginning of the experiments the formed peroxy radicals $\left(\mathrm{RO}_{2}\right)$ will predominantly react through the $\mathrm{NO}$ pathway, while in the later parts of the experiments the $\mathrm{HO}_{2}$ pathway will be of increasing importance. Simulations with the Master Chemical Mechanism version 3.2 (MCMv3.2) showed that the fraction reacting in the $\mathrm{HO}_{2}$ pathway is about 5-7\% at 2 ppb NO. Light aromatics which react via the NO pathway are likely to form products that are too volatile to end up in the particle phase, when oxidized at the $\mathrm{OH}$ radical concentration used here ( $\mathrm{Ng}$ et al. 2007), thus explaining the observed delay in SOA formation. For the $\mathrm{H}_{2} \mathrm{O}_{2}$ "high $\mathrm{NO}_{\mathrm{x}}$ " experiments in the literature, $\mathrm{NO}$ was converted to $\mathrm{NO}_{2}$ within minutes. Thus SOA formation for that case and in the case without added $\mathrm{NO}_{\mathrm{x}}$ may have been dominated by the $\mathrm{HO}_{2}$ pathway throughout the majority of the experiment, which may explain the higher yields found in these studies.

According to the fits, the apparent mass yield of the gasoline exhaust from intermediate idling is about 1.7 times higher than the yield of the pure precursors under the conditions in this study. Thus, about 1.7 times more $\mathrm{C}_{6}-\mathrm{C}_{9}$ light aromatics have been reacted in the precursor experiments to form the same mass concentration of SOA (Eq. 2). At a low cumulative $\mathrm{OH}$ exposure of $3 \times 10^{6}$ the ratio was 1.9 (Fig. S5), consistent with an earlier onset of SOA formation in gasoline exhaust compared to light aromatic precursors. If we assume that the reacted $\mathrm{C}_{6}-\mathrm{C}_{9}$ aromatic precursors form the same amount of SOA in the complex mixture in the gasoline exhaust as they do in the pure precursor experiments, this would indicate that about $60 \%$ of the SOA in the gasoline exhaust originates from $\mathrm{C}_{6}-\mathrm{C}_{9}$ precursors and $40 \%$ from additional precursors (Fig. 5). The cold start experiment was an exception as it falls essentially on the fit of the yield of pure precursors.

The percentages of the total reacted light aromatics in the idling gasoline exhaust were for each light aromatic on average $0.9 \%$ benzene, $9.3 \%$ toluene, $29.1 \% \mathrm{C}_{8}, 41.5 \% \mathrm{C}_{9}$, $17.2 \% \mathrm{C}_{10}$, and $2.0 \% \mathrm{C}_{11}$. Assuming that the $\mathrm{C}_{10}$ and $\mathrm{C}_{11}$ light aromatics have similar yields as the $\mathrm{C}_{8}-\mathrm{C}_{9}$ aromatics,
$\mathrm{C}_{10}$ and $\mathrm{C}_{11}$ aromatics would be responsible for about $11 \%$ and $1 \%$, respectively, of the SOA formed. Additional candidates as SOA precursors will be discussed in Sect. 3.4.

The fraction of emitted $\mathrm{C}_{10}$ and $\mathrm{C}_{11}$ light aromatics and naphthalene were all substantially lower in the cold start experiment, which is consistent with the classical $\mathrm{C}_{6}-\mathrm{C}_{9}$ aromatics being responsible for a larger fraction of the formed $\mathrm{SOA}$ in this case. Thus, SOA formation from cold start emissions but not from idling could be well described by only including the $\mathrm{C}_{6}-\mathrm{C}_{9}$ light aromatics.

Our gasoline exhaust experiments were carried out at relatively high total VOC-to- $\mathrm{NO}_{\mathrm{x}}$ ratios. The ratios were 8-70 (in ppb VOC per ppb $\mathrm{NO}_{\mathrm{x}}$ ), compared to $\sim 7$ for the precursor experiments. This is higher than those found in gasoline exhaust emission tests and downwind urban areas, typically 0.5-10 (Clairotte et al., 2013). However, still the NO pathway for $\mathrm{RO}_{2}$ reactions strongly dominated in the first 45$60 \mathrm{~min}$ of each experiment. It is important to note that SOA formation starts at a higher $\mathrm{NO}$ concentration in the gasoline exhaust experiments compared to the pure precursor experiments. Particularly in experiment I3 (which started from the highest NO level), there is evidence for sustained SOA production at elevated $\mathrm{NO}$ (for example $10 \mu \mathrm{g} \mathrm{m}^{-3} \mathrm{SOA}$ formed at $\mathrm{NO}>20 \mathrm{ppb}$ as shown in Fig. S6). So while a majority of the SOA formation in the gasoline exhaust experiments may have occurred via the $\mathrm{HO}_{2}$ pathway, we suggest that gasoline exhaust may contain precursors (for example naphthalenes) that have a yield in the "high $\mathrm{NO}_{\mathrm{x}}$ regime" that is larger than that of, for example, m-xylene.

\subsection{Chemical composition of SOA}

High-resolution SOA mass spectra from experiments I2 and P1 are shown in Fig. 6. The AMS ion fragments have been grouped into four families based on their carbon, hydrogen and oxygen content. The dominating organic $\mathrm{m} / \mathrm{z}$ peaks in SOA from gasoline exhaust are $\mathrm{m} / \mathrm{z}, 4$ followed by $\mathrm{m} / \mathrm{z}, 43$ (Fig. 6 upper panel), while the reverse trend was found in the precursor experiments (Fig. 6 lower panel).

The peaks at $m / z, 43$ and 44 were dominated by $\mathrm{C}_{2} \mathrm{H}_{3} \mathrm{O}^{+}$ and $\mathrm{CO}_{2}^{+}$fragments, respectively, for both the gasoline exhaust and the precursor experiments. These two are the most abundant fragments in ambient oxygenated organic aerosol (OOA). $\mathrm{CO}_{2}^{+}$is typically the main fragment for low-volatility OOA (LV-OOA), while in semi-volatile OOA (SV-OOA) $\mathrm{CO}_{2}^{+}$and $\mathrm{C}_{2} \mathrm{H}_{3} \mathrm{O}^{+}$are of similar magnitude (Ng et al., 2010).

The gasoline SOA mass spectrum (Fig. 6) shows strong similarities to atmospheric observations of fresh OOA detected in and downwind of urban areas, and gasoline SOA may thus be an important contributor to SOA in these locations as recently hypothesized from ambient data (Bahreini et al., 2012). Although SOA from many different sources show similarities, a few differences compared to diesel exhaust SOA should be pointed out. For example, diesel SOA (Chirico et al., 2010) has significant contributions from 


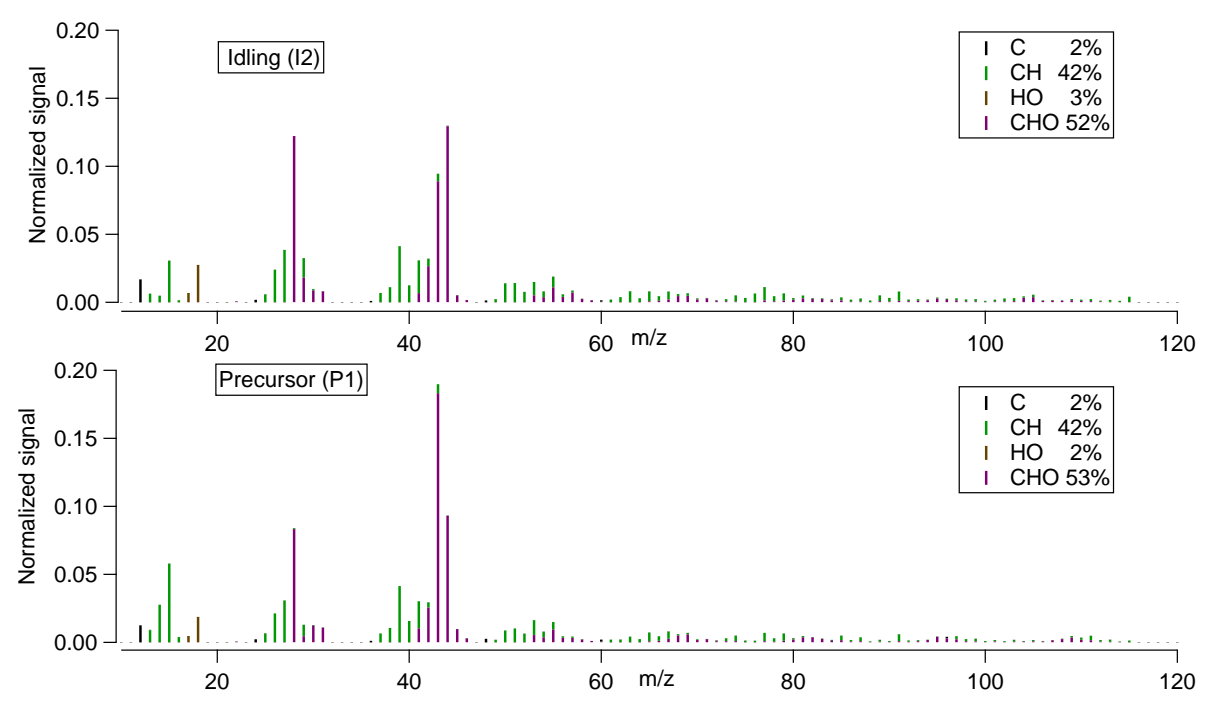

Fig. 6. Normalized high-resolution MS of OA at the end of gasoline exhaust experiment $\mathrm{I} 2$ and precursor mixture experiment $\mathrm{P} 1$ (toluene, $\mathrm{m}$-xylene, 1,2,4-TMB). The ion fragments detected have been grouped into four families: $\mathrm{C}$ containing only carbon; $\mathrm{CH}$ containing only carbon and hydrogen; HO containing only oxygen and hydrogen; and CHO containing carbon, hydrogen and oxygen. The POA contribution in experiment $\mathrm{I} 2$ was $<0.5 \%$.

hydrocarbon fragments in the $\mathrm{C}_{n} \mathrm{H}_{2 n+1}$ series (for example $\mathrm{C}_{3} \mathrm{H}_{7}^{+}$and $\mathrm{C}_{4} \mathrm{H}_{9}^{+}$). The main hydrocarbon fragments in the gasoline SOA are instead $\mathrm{C}_{3} \mathrm{H}_{3}^{+}$and $\mathrm{C}_{3} \mathrm{H}_{5}^{+}$, consistent with aromatic (and potentially also alkene) precursors that have a $\mathrm{H} / \mathrm{C}$ ratio closer to 1 .

The organic mass fraction detected at $\mathrm{m} / z 43\left(f_{43}\right)$ and $m / z 44\left(f_{44}\right)$ from the AMS measurements at the end of each experiment is shown in Fig. 7a. The figure also features the triangular boundary of atmospheric OOA observations introduced by $\mathrm{Ng}$ et al. (2010). Photochemical aging in the atmosphere typically increases the $f_{44}$ in the organic spectra; a relatively high $f_{44}$ indicates that the atmospheric aging process is more progressed.

The concept of the triangular space is formulated for atmospheric measurements of aged aerosols from multiple precursors and sources. Since gasoline exhaust SOA is a more complex mixture than SOA from pure precursors, it can be expected that gasoline SOA resembles atmospheric observations better than SOA from pure precursors. It is also apparent that SOA from a relevant mixture of light aromatics is not able to adequately simulate the composition of the SOA from early aging of gasoline exhaust.

For one idling and one precursor experiment we have plotted the $f_{43}$ vs. $f_{44}$ relationship as a function of cumulative $\mathrm{OH}$ exposure. A cumulative $\mathrm{OH}$ exposure of $9 \times 10^{6} \mathrm{~cm}^{-3} \mathrm{~h}$ corresponds to $9 \mathrm{~h}$ of aging at a $24 \mathrm{~h}$ mean $\mathrm{OH}$ concentration of $1 \times 10^{6} \mathrm{~cm}^{-3}$. For the SOA in the idling experiment there is an increase in both $f_{43}$ and $f_{44}$ with increasing $\mathrm{OH}$ exposure, while for the precursor mixture the $f_{43} / f_{44}$ relationship is little influenced.

A van Krevelen diagram, showing the hydrogen-to-carbon $(\mathrm{H}: \mathrm{C})$ and oxygen-to-carbon $(\mathrm{O}: \mathrm{C})$ ratios is shown in
Fig. 7b. The diagram depicts the molar ratios at the end of each experiment. The $\mathrm{H}: \mathrm{C}$ ratio varies between 1.2 and 1.55 and the $\mathrm{O}: \mathrm{C}$ ratio 0.36 to 0.43 for the set of experiments, and there is no systematic difference between gasoline exhaust and pure precursor experiments in this aspect. A higher $\mathrm{O}: \mathrm{C}$ and lower $\mathrm{H}: \mathrm{C}$ ratio represent a higher oxidation state. Average carbon oxidation $\left(\mathrm{OS}_{\mathrm{C}}\right)$ state can be estimated from the $\mathrm{O}: \mathrm{C}$ and $\mathrm{H}: \mathrm{C}$ data (Kroll et al., 2011). The SOA produced in these experiments have $\mathrm{OS}_{\mathrm{C}}$ ranging from -0.8 to -0.4 , similar to SV-OOA in the atmosphere. The diagonal red lines indicate oxidation states $-1,-0.5$ and 0 .

An important observation is that the idling gasoline exhaust and pure precursor experiments are clearly separated in terms of their $f_{43} / f_{44}$ relationship but not in terms of their $\mathrm{O}: \mathrm{C}$ vs. $\mathrm{H}: \mathrm{C}$ relationship and the division of ion fragments into four different families dependent on their composition. This is not contradictory since $\mathrm{m} / \mathrm{z} 44$ and 43 only represent a fraction of the organic MS, while the atomic ratios are calculated from the full spectra. A higher abundance of $\mathrm{C}_{2} \mathrm{H}_{3} \mathrm{O}^{+}$(the main fragment at $\mathrm{m} / z, 43$ in these data) pulls the $\mathrm{O}: \mathrm{C}$ ratio towards 0.5 and the $\mathrm{H}: \mathrm{C}$ ratio towards 1.5 . The remaining fraction of the precursor SOA mass spectrum compensates for this effect.

The experimentally observed $f_{43}, f_{44}$ values of SOA from this study are compared with literature data for light aromatic precursors in Fig. 8. The precursor experiments reported here are in general agreement with previous studies of SOA from pure $\mathrm{m}$-xylene and 1,3,5-TMB (Ng et al., 2010), both positioned to the right of the triangular plot.

From literature values of the fragmentation patterns of the dominating $\mathrm{C}_{6}-\mathrm{C}_{9}$ light aromatic compounds, we calculated the theoretically expected fragmentation pattern of 

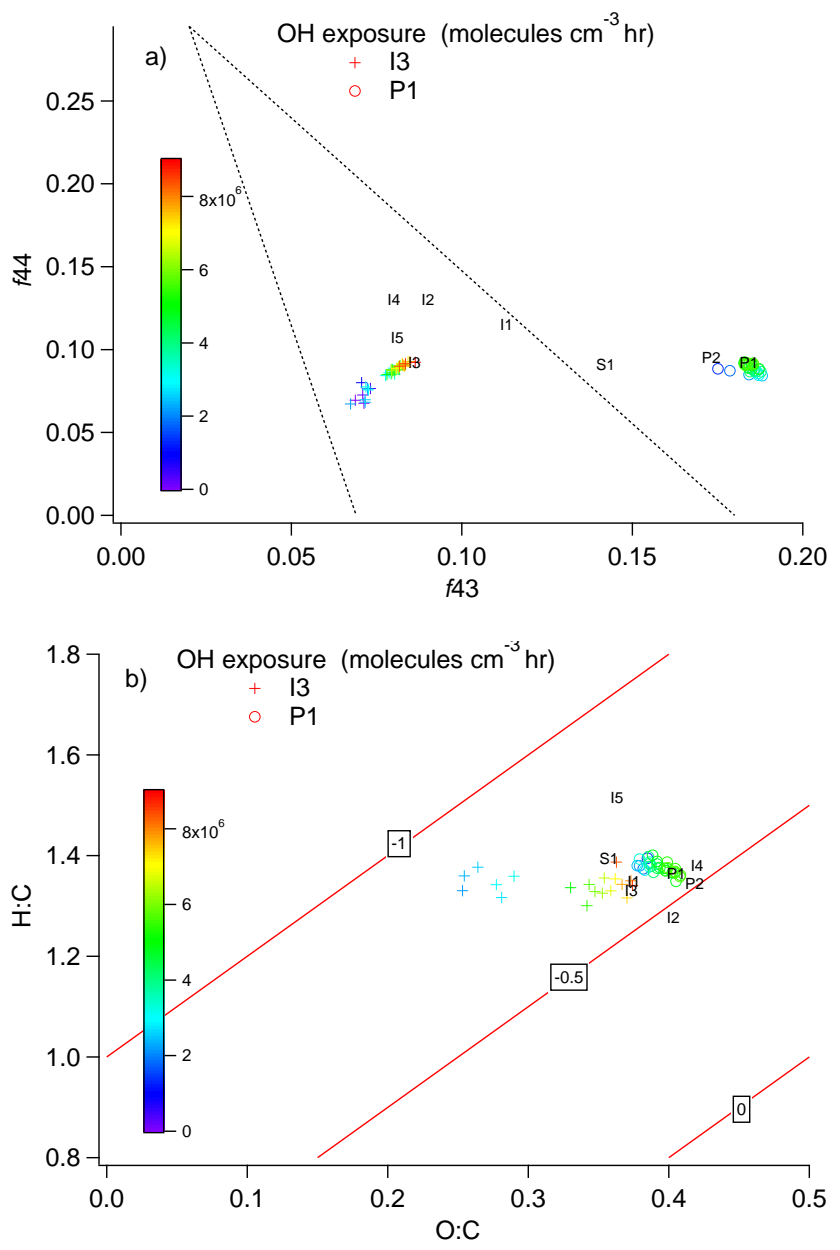

Fig. 7. (a) The mass fraction of organic signal at $m / z 44\left(f_{44}\right) \mathrm{vs.}$ $m / z, 43\left(f_{43}\right)$ at the end of each experiment, (b) $\mathrm{H}: \mathrm{C}$ vs. O : C of the $\mathrm{OA}$ at the end of each experiment. The triangular space in (a) indicates the range which covers the majority of atmospheric OOA observations ( $\mathrm{Ng}$ et al., 2010). The diagonal lines in (b) indicate estimated average carbon oxidation states $-1,-0.5$ and 0 (Kroll et al., 2011). For experiments $\mathrm{I} 3$ (+) and P1 (o) the data are plotted as a function of $\mathrm{OH}$ exposure. The cumulative $\mathrm{OH}$ exposure was $8.5 \times 10^{6}$ molecule $\mathrm{cm}^{-3} \mathrm{~h}$ in $\mathrm{I} 3$ and $6.4 \times 10^{6}$ molecule $\mathrm{cm}^{-3} \mathrm{~h}$ in $\mathrm{P} 1$ at the end of the experiments. The first point in experiment I3 corresponds to the time when SOA made up $\sim 90 \%$ of the OA mass concentration.

the gasoline exhaust assuming that only the $\mathrm{C}_{6}-\mathrm{C}_{9}$ light aromatic compounds were contributing to the SOA. It was assumed that the fragmentation pattern of the mixed SOA could be determined as the weighted sum of the fragmentation patterns of SOA from the individual precursors. The theoretically expected $f_{43}$ and $f_{44}$ values are also plotted in Fig. 8. The procedure and the literature data to this calculation are shown in more detail in the Supplement.

It is found (Fig. 8) that the theoretically expected $f_{43}$ for the gasoline exhaust experiments, calculated as described above, is slightly lower than for the pure precursor experi-

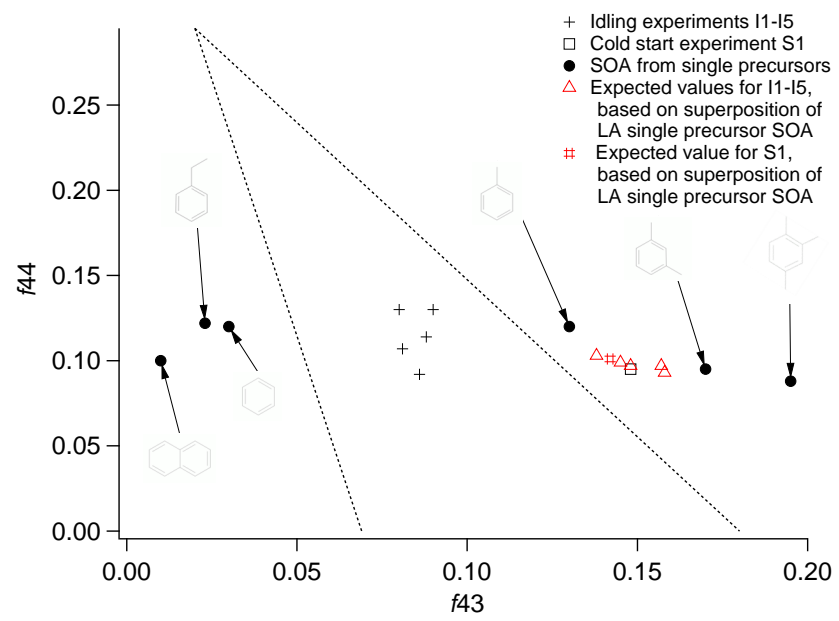

Fig. 8. The $f_{43}$ and $f_{44}$ for experiments I1-I5 (+) and for SOA formed from single precursors plotted together with the triangle from $\mathrm{Ng}$ et al. (2010). Also plotted are expected values for I1-I5 if only LA contributed to SOA formation, assuming superposition of the mass spectra for single precursor SOA. For experiments I1 and $\mathrm{S} 1$, a correction had to be made due to non-negligible POA contribution to OA. The $f_{44}$ to $f_{43}$ of SOA from precursors featured in the figure are retrieved from the following sources: benzene (Ng et al., 2010), toluene (Chhabra et al., 2011), ethylbenzene (Sato et al., 2010), m-xylene (experiment P2, this study), 1,2,4trimethylbenzene (derived from exp. P1) and naphthalene (Chhabra et al., 2011). The results suggest no more than $60 \%$ of SOA in I1-I5 were due to $\mathrm{C}_{6}-\mathrm{C}_{9}$ LA precursors, assuming that the MS of gasoline exhaust SOA can be estimated as a weighted mean of the MS of SOA from single precursors. See Table S4 (in the Supplement) for more details about these calculations.

ments, but still substantially higher than that experimentally found in the idling experiments. The small difference between the expected $f_{43}$ and the three-component precursor mixture used in our experiment (P1) is due to the low $f_{43}$ of ethyl benzene SOA and slightly higher toluene content in the gasoline exhaust compared to experiment P1. From this analysis we can put constraints on the magnitude and composition of SOA from the additional precursors discussed above.

If we subtract the expected $f_{43}$ and $f_{44}$ fractions (based on only $\mathrm{C}_{6}-\mathrm{C}_{9}$ aromatics) from the SOA mass spectra at the end of each gasoline exhaust experiment, it can be shown that a maximum of $50-60 \%$ of the SOA mass would come from light aromatics (Table S4 in the Supplement). At higher fractions of light aromatic precursors, the $f_{43}$ SOA value of the unknown additional precursors would become below 0 . In contrast, for the cold start experiment, the $f_{43} / f_{44}$ relationship of SOA assuming only $\mathrm{C}_{6}-\mathrm{C}_{9}$ precursors is almost identical to the experimentally found value, again supporting the notion that the cold start emissions can be explained from essentially $\mathrm{C}_{6}$ to $\mathrm{C}_{9}$ light aromatics only.

This indicates that the additional precursors are likely to produce SOA with low $f_{43}$, to the left of the triangle in Fig. 8. Possible precursors for the non-light aromatic SOA 
that do produce SOA with low $f_{43}$ are two-ring PAHs such as naphthalene (Fig. 8), which have been identified as important SOA precursors in aging of diesel exhaust (Chan et al., 2009).

Naphthalene has also previously been quantified in gasoline exhaust at similar proportions compared to the sum of $\mathrm{C}_{6}-\mathrm{C}_{9}$ light aromatics (Schauer et al., 2002) as was found in the idling experiments here. The mass yield from tworing PAHs in low- $\mathrm{NO}_{\mathrm{x}}$ and high- $\mathrm{NO}_{\mathrm{x}}$ photooxidation experiments (Chan et al., 2009) is about two and four times greater respectively, than the mass yield from similar experiments with $\mathrm{m}$-xylene as precursor ( $\mathrm{Ng}$ et al., 2007). This implies that relatively low concentrations of PAHs can give a significant contribution to SOA formation.

We used our measured initial naphthalene concentration and the known $\mathrm{OH}$ reactivity to calculate the reacted concentration of naphthalene, and assumed that the mass yield for naphthalene is three times higher than the yield for $\mathrm{m}$ xylene in our chamber under the conditions studied. We found that naphthalene could contribute with around 5\% of the SOA mass in experiments I1 and I2. Results from Schauer et al. (2002) suggested that the summed concentration of 1- and 2-methyl naphthalene could be up to $150 \%$ of the naphthalene concentration in gasoline exhaust, but those were not measured in our experiments. If and when methylnaphthalenes are present in such significant concentrations, they would have to be considered as important SOA precursors in the early aging of gasoline exhaust due to their high yield and $\mathrm{OH}$ reactivity (Chan et al., 2009). The result of superposition of SOA from light aromatic and naphthalene precursors in the "Ng triangle" would decrease the discrepancy in composition between expected and measured values for gasoline exhaust.

As discussed above, we also estimated that $\mathrm{C}_{10}$ and $\mathrm{C}_{11}$ aromatics could together contribute to about $10-15 \%$ of the SOA in experiments I1 and I2. If the experiments had proceeded to a higher cumulative $\mathrm{OH}$ exposure, it is likely that a larger fraction of the formed SOA would originate from $\mathrm{C}_{6}$ to $\mathrm{C}_{9}$ aromatics, since these occur in higher concentration but have a lower $\mathrm{OH}$ reactivity than the larger aromatic molecules, The shift towards higher $f_{43}$ and $f_{44}$ with increasing cumulative $\mathrm{OH}$ exposure shown for experiment $\mathrm{I} 3$ is consistent with naphthalenes being a major contributor in the early phase of SOA formation in gasoline exhaust.

In addition to the $\mathrm{C}_{10}$ and $\mathrm{C}_{11}$ light aromatics and naphthalenes, a minor part of the remaining SOA may possibly be formed by other IVOCs such as phenols (that also produce low $f_{43}$ SOA (Chhabra et al., 2011)), aromatic aldehydes, long-chain and branched alkanes and alkenes, and highly reactive compounds (such as styrene). SOA from alkanes is rich in $\mathrm{C}_{\mathrm{x}} \mathrm{H}_{(2 x+1)}$ fragments, e.g., $m / z=43,57,71$, etc. (Miracolo et al., 2010). The SOA formed from gasoline exhaust had low contribution of these fragments, which suggests that alkanes are of minor importance as a SOA precursor in the gasoline exhaust experiments. It can also not be ruled out that reactions with $\mathrm{NO}_{3}$ (which is not effectively photolyzed by black lights) was contributing to SOA formation. However, the SOA yields of $\mathrm{NO}_{3}$ reactions, for example with most of the short alkenes $(\mathrm{C}<10)$ occurring in gasoline exhaust, are expected to be lower than yields for light aromatics. Finally, an additional potentially important effect could be that photo-oxidation of light aromatics in a more complex mixture, like gasoline exhaust, results in more complex reaction products and SOA with different composition, and an altered SOA yield compared to pure precursor experiments (Song et al., 2007).

\subsection{SOA production factors}

SOA production factors (PF) $\left(\mathrm{g} \mathrm{kg}^{-1}\right)$ are calculated using Eq. (3), where the numerator is the SOA concentration $\left(\mu \mathrm{g} \mathrm{m}^{-3}\right)$ and the denominator is the concentration of total combusted carbon $\left(\mu \mathrm{g} \mathrm{m}^{-3}\right) . \omega_{c}$ is the carbon content in fuel, which is 0.85 (Kirchstetter et al., 1999). HC is the total hydrocarbons in the raw exhaust, $\mathrm{BC}$ is the black carbon emitted and we assume that all organic carbon is emitted in gas phase.

$\mathrm{PF}=10^{3}\left([\mathrm{SOA}] /\left(\left[\mathrm{CO}_{2}\right]+[\mathrm{CO}]+[\mathrm{HC}]+[\mathrm{BC}]\right)\right) \omega_{c}$

The SOA production factors ranged between 0.005 and $0.09 \mathrm{~g} \mathrm{~kg}^{-1}(0.005-0.05$ at cumulative $\mathrm{OH}$ exposure $\sim 5 \times 10^{6} \mathrm{~cm}^{-3} \mathrm{~h}$ ) for the idling experiments; the PF for the cold start experiment was $0.48 \mathrm{~g} \mathrm{~kg}^{-1}$. Compared to emission factors from diesel passenger vehicles reported by Chirico et al. (2010), the PF from the cold start is in the same range as the PF from diesel vehicles with deactivated oxidation catalyst $\left(0.254\right.$ to $\left.0.461 \mathrm{~g} \mathrm{~kg}^{-1}\right)$. The PF from idling gasoline vehicles is similar to or higher than that for diesel vehicles with functioning catalyst $\left(0.012-0.020 \mathrm{~g} \mathrm{~kg}^{-1}\right.$ ) (Chirico et al., 2010). Platt et al. (2012) have reported a SOA production factor of $0.345 \mathrm{~g} \mathrm{~kg}^{-1}$ for a single gasoline vehicle undergoing the New European Driving Cycle (NEDC).

It is important to note that the reported gasoline SOA production factors only relate to cold idling and cold start operating modes investigated for several vehicles (this study) and a single vehicle using a full driving cycle (Platt et al. 2012). Clearly there is need for more data to systematically investigate a larger set of operating modes, engine types, and exhaust after treatment systems at well-defined oxidant levels in parallel with field observations of gasoline SOA formation in the atmosphere. The elevated emissions due to cold starts at reduced ambient temperatures will typically be accompanied by lower $\mathrm{OH}$ concentrations in the atmosphere. So these emissions will therefore contribute to SOA formation for a longer time period. The RH was around 5\% in our study; it will also be important to investigate the effect of increased RH on gasoline exhaust SOA yield and composition.

It should be pointed out that the results of this study, when combined with the conclusions by Bahreini et al. (2012), are not fully consistent with the results of de Gouw et al. (2008). 
We found that a substantial fraction (up to $60 \%$ ) of the gasoline SOA is formed by light aromatics, while de Gouw et al. (2008) showed that a dominating fraction of urban SOA is formed from precursors other than light aromatics; thus more research is needed on SOA formation in urban areas.

\section{Conclusions}

The VOC emissions in gasoline exhaust have a substantial contribution of $\mathrm{C}_{6}-\mathrm{C}_{9}$ light aromatic compounds that are known SOA precursors. As shown in this study, gasoline exhaust readily forms secondary organic aerosol with a signature aerosol mass spectrum with similarities to the oxidized organic aerosol that commonly dominates the OA mass spectra in and downwind of urban areas. This substantiates recent claims that gasoline SOA is a dominating source to SOA in and downwind of large metropolitan areas. Evidence for additional SOA precursors that are responsible for $40 \%$ or more of the formed gasoline SOA during idling has been shown using two independent approaches. These were based on (1) the difference in apparent mass yield and (2) the difference in chemical composition between SOA from gasoline exhaust and that of pure precursors. Important candidate contributors are higher-order aromatic compounds such as $\mathrm{C}_{10}$ and $\mathrm{C}_{11}$ light aromatics, naphthalenes and methylnaphthalenes. In contrast, during a cold start experiment, the distribution of light aromatics was consistent with vaporized fuel, and the apparent mass yield and the aerosol mass spectra were both consistent with $\mathrm{C}_{6}-\mathrm{C}_{9}$ light aromatics being responsible for more than $90 \%$ of the SOA formation.

\section{Supplementary material related to this article is available online at: http://www.atmos-chem-phys.net/13/ 6101/2013/acp-13-6101-2013-supplement.pdf.}

Acknowledgements. This work was supported by the Swedish Research Council for Environment, Agricultural Sciences and Spatial Planning FORMAS through projects 2008-1467, 2009-615 and 2010-1678, the Swedish Research Council through project 2006-5940 and by Metalund, the center for Medicine and Technology for Working Life and Society, a competence center at Lund University, Sweden, supported by FAS, the Swedish Council for Working Life and Social Research.

Edited by: N. M. Donahue

\section{References}

Aiken, A. C., Decarlo, P. F., Kroll, J. H., Worsnop, D. R., Huffman, J. A., Docherty, K. S., Ulbrich, I. M., Mohr, C., Kimmel, J. R., Sueper, D., Sun, Y., Zhang, Q., Trimborn, A., Northway, M., Ziemann, P. J., Canagaratna, M. R., Onasch, T. B., Alfarra, M. R., Prevot, A. S. H., Dommen, J., Duplissy, J., Metzger, A., Baltensperger, U., and Jimenez, J. L.: O/C and OM/OC ratios of primary, secondary, and ambient organic aerosols with high-resolution time-of-flight aerosol mass spectrometry, Environ. Sci. Technol., 42, 4478-4485, 2008.

Bahreini, R., Middlebrook, A. M., de Gouw, J. A., Warneke, C., Trainer, M., Brock, C. A., Stark, H., Brown, S. S., Dube, W. P., Gilman, J. B., Hall, K., Holloway, J. S., Kuster, W. C., Perring, A. E., Prevot, A. S. H., Schwarz, J. P., Spackman, J. R., Szidat, S., Wagner, N. L., Weber, R. J., Zotter, P., and Parrish, D. D.: Gasoline emissions dominate over diesel in formation of secondary organic aerosol mass, Geophys. Res. Lett., 39, L06805, doi:10.1029/2011GL050718, 2012.

Bruehlmann, S., Novak, P., Lienemann, P., Trottmann, M., Gfeller, U., Zwicky, C. N., Bommer, B., Huber, H., Wolfensberger, M., and Heeb, N. V.: Three-way-catalyst induced benzene formation: A precursor study, Appl. Catal. B-Environ., 70, 276-283, 2007.

Carter, W. P. L., Cocker, D. R., Fitz, D. R., Malkina, I. L., Bumiller, K., Sauer, C. G., Pisano, J. T., Bufalino, C., and Song, C.: A new environmental chamber for evaluation of gas-phase chemical mechanisms and secondary aerosol formation, Atmos. Environ., 39, 7768-7788, 2005.

Chan, A. W. H., Kautzman, K. E., Chhabra, P. S., Surratt, J. D., Chan, M. N., Crounse, J. D., Kürten, A., Wennberg, P. O., Flagan, R. C., and Seinfeld, J. H.: Secondary organic aerosol formation from photooxidation of naphthalene and alkylnaphthalenes: implications for oxidation of intermediate volatility organic compounds (IVOCs), Atmos. Chem. Phys., 9, 3049-3060, doi:10.5194/acp-9-3049-2009, 2009.

Chhabra, P. S., Ng, N. L., Canagaratna, M. R., Corrigan, A. L., Russell, L. M., Worsnop, D. R., Flagan, R. C., and Seinfeld, J. H.: Elemental composition and oxidation of chamber organic aerosol, Atmos. Chem. Phys., 11, 8827-8845, doi:10.5194/acp-11-88272011, 2011.

Chirico, R., DeCarlo, P. F., Heringa, M. F., Tritscher, T., Richter, R., Prévôt, A. S. H., Dommen, J., Weingartner, E., Wehrle, G., Gysel, M., Laborde, M., and Baltensperger, U.: Impact of aftertreatment devices on primary emissions and secondary organic aerosol formation potential from in-use diesel vehicles: results from smog chamber experiments, Atmos. Chem. Phys., 10, 11545-11563, doi:10.5194/acp-10-11545-2010, 2010.

Clairotte, M., Adam, T. W., Zardini, A. A., Manfredi, U., Martini, G., Krasenbrink, A., Vicet, A., Tournie, E., and Astorga, C.: Effects of low temperature on the cold start gaseous emissions from light duty vehicles fuelled by ethanol-blended gasoline, Appl. Energ., 102, 44-54, 2013.

Cocker, D. R., Mader, B. T., Kalberer, M., Flagan, R. C., and Seinfeld, J. H. The effect of water on gas-particle partitioning of secondary organic aerosol: II. m-xylene and 1,3,5-trimethylbenzene photooxidation systems, Atmos. Environ., 35, 6073-6085, 2001.

de Gouw, J. and Jimenez, J. L.: Organic Aerosols in the Earth's Atmosphere, Environ. Sci. Technol., 43, 7614-7618, 2009.

de Gouw, J. and Warneke, C.: Measurements of volatile organic compounds in the earths atmosphere using proton-transfer- 
reaction mass spectrometry, Mass Spectrom. Rev. 26, 223-257, 2007.

de Gouw, J. A., Brock, C. A., Atlas, E. L., Bates, T. S., Fehsenfeld, F. C., Goldan, P. D., Holloway, J. S., Kuster, W. C., Lerner, B. M., Matthew, B. M., Middlebrook, A. M., Onasch, T. B., Peltier, R. E., Quinn, P. K., Senff, C. J., Stohl, A., Sullivan, A. P., Trainer, M., Warneke, C., Weber, R. J., and Williams, E. J.: Sources of particulate matter in the northeastern United States in summer: 1. Direct emissions and secondary formation of organic matter in urban plumes, J. Geophys. Res.-Atmos., 113, D08301, doi:10.1029/2007JD009243, 2008.

DeCarlo, P. F., Kimmel, J. R., Trimborn, A., Northway, M. J., Jayne, J. T., Aiken, A. C., Gonin, M., Fuhrer, K., Horvath, T., Docherty, K. S., Worsnop, D. R., and Jimenez, J. L.: Field-deployable, high-resolution, time-of-flight aerosol mass spectrometer, Anal Chem 78, 8281-8289, 2006.

Elghawi, U. M., Mayouf, A., Tsolakis, A., and Wyszynski, M. L.: Vapour-phase and particulate-bound PAHs profile generated by a (SI/HCCI) engine from a winter grade commercial gasoline fuel, Fuel 89, 2019-2025, 2010.

Gentner, D. R., Isaacman, G., Worton, D. R., Chan, A. W. H., Dallmann, T. R., Davis, L., Liu, S., Day, D. A., Russell, L. M., Wilson, K. R., Weber, R., Guha, A., Harley, R. A., and Goldstein, A. H.: Elucidating secondary organic aerosol from diesel and gasoline vehicles through detailed characterization of organic carbon emissions, Proc. Natl. Acad. Sci. 109, 18318-18323, 2012.

Gerboles, M., Lagler, F., Rembges, D., and Brun, C.: Assessment of uncertainty of $\mathrm{NO} 2$ measurements by the chemiluminescence method and discussion of the quality objective of the NO2 European Directive, J. Environ. Monitor. 5, 529-540, 2003.

Grieshop, A. P., Donahue, N. M., and Robinson, A. L.: Laboratory investigation of photochemical oxidation of organic aerosol from wood fires 2: analysis of aerosol mass spectrometer data, Atmos. Chem. Phys., 9, 2227-2240, doi:10.5194/acp-9-2227-2009, 2009.

Hallquist, M., Wenger, J. C., Baltensperger, U., Rudich, Y., Simpson, D., Claeys, M., Dommen, J., Donahue, N. M., George, C., Goldstein, A. H., Hamilton, J. F., Herrmann, H., Hoffmann, T., Iinuma, Y., Jang, M., Jenkin, M. E., Jimenez, J. L., Kiendler-Scharr, A., Maenhaut, W., McFiggans, G., Mentel, Th. F., Monod, A., Prévôt, A. S. H., Seinfeld, J. H., Surratt, J. D., Szmigielski, R., and Wildt, J.: The formation, properties and impact of secondary organic aerosol: current and emerging issues, Atmos. Chem. Phys., 9, 5155-5236, doi:10.5194/acp-9-51552009, 2009.

Heeb, N. V., Forss, A. M., Bruhlmann, S., Luscher, R., Saxer, C. J., and Hug, P.: Three-way catalyst-induced formation of ammoniavelocity- and acceleration-dependent emission factors, Atmos. Environ., 40, 5986-5997, 2006.

Hildebrandt, L., Donahue, N. M., and Pandis, S. N.: High formation of secondary organic aerosol from the photo-oxidation of toluene, Atmos. Chem. Phys., 9, 2973-2986, doi:10.5194/acp-92973-2009, 2009.

Jobson, B. T., Volkamer, R. A., Velasco, E., Allwine, G., Westberg, H., Lamb, B. K., Alexander, M. L., Berkowitz, C. M., and Molina, L. T.: Comparison of aromatic hydrocarbon measurements made by PTR-MS, DOAS and GC-FID during the MCMA 2003 Field Experiment, Atmos. Chem. Phys., 10, 1989-2005, doi:10.5194/acp-10-1989-2010, 2010.
Kean, A. J., Littlejohn, D., Ban-Weiss, G. A., Harley, R. A., Kirchstetter, T. W., and Lunden, M. M.: Trends in on-road vehicle emissions of ammonia. Atmos. Environ., 43, 1565-1570, 2009.

Kirchstetter, T. W., Harley, R. A., Kreisberg, N. M., Stolzenburg, M. R., and Hering, S. V.: On-road measurement of fine particle and nitrogen oxide emissions from light- and heavy-duty motor vehicles, Atmos. Environ. 33, 2955-2968, 1999.

Kleindienst, T. E., Corse, E. W., Li, W., McIver, C. D., Conver, T. S., Edney, E. O., Driscoll, D. J., Speer, R. E., Weathers, W. S., and Tejada, S. B.: Secondary organic aerosol formation from the irradiation of simulated automobile exhaust, J Air Waste Manage., 52, 259-272, 2002.

Kroll, J. H., Donahue, N. M., Jimenez, J. L., Kessler, S. H., Canagaratna, M. R., Wilson, K. R., Altieri, K. E., Mazzoleni, L. R., Wozniak, A. S., Bluhm, H., Mysak, E. R., Smith, J. D., Kolb, C. E., and Worsnop, D. R.: Carbon oxidation state as a metric for describing the chemistry of atmospheric organic aerosol, Nat. Chem. 3, 133-139, 2011.

Legreid, G., Reimann, S., Steinbacher, M., Staehelin, J., Young, D., and Stemmler, K.: Measurements of OVOCs and NMHCs in a swiss highway tunnel for estimation of road transport emissions, Environ. Sci. Technol. 41, 7060-7066, 2007.

Lindinger, W., Hansel, A., and Jordan, A.: On-line monitoring of volatile organic compounds at pptv levels by means of protontransfer-reaction mass spectrometry (PTR-MS) - Medical applications, food control and environmental research. Int. J. Mass Spectrom. 173, 191-241, 1998.

Löndahl, J., Pagels, J., Boman, C., Swietlicki, E., Massling, A., Rissler, J., Blomberg, A., Bohgard, M., and Sandstrom, T.: Deposition of biomass combustion aerosol particles in the human respiratory tract, Inhal. Toxicol., 20, 923-933, 2008.

McMurry, P. H. and Rader, D. J.: Aerosol Wall Losses in Electrically Charged Chambers, Aerosol Sci. Technol., 4, 249-268, 1985.

Miracolo, M. A., Presto, A. A., Lambe, A. T., Hennigan, C. J., Donahue, N. M., Kroll, J. H., Worsnop, D. R., and Robinson, A. L.: Photo-Oxidation of Low-Volatility Organics Found in Motor Vehicle Emissions: Production and Chemical Evolution of Organic Aerosol Mass, Environ. Sci. Technol., 44, 1638-1643, 2010.

Miracolo, M. A., Hennigan, C. J., Ranjan, M., Nguyen, N. T., Gordon, T. D., Lipsky, E. M., Presto, A. A., Donahue, N. M., and Robinson, A. L.: Secondary aerosol formation from photochemical aging of aircraft exhaust in a smog chamber, Atmos. Chem. Phys., 11, 4135-4147, doi:10.5194/acp-11-4135-2011, 2011.

Monks, P. S., Granier, C., Fuzzi, S., Stohl, A., Williams, M. L., Akimoto, H., Amann, M., Baklanov, A., Baltensperger, U., Bey, I., Blake, N., Blake, R. S., Carslaw, K., Cooper, O. R., Dentener, F., Fowler, D., Fragkou, E., Frost, G. J., Generoso, S., Ginoux, P., Grewe, V., Guenther, A., Hansson, H. C., Henne, S., Hjorth, J., Hofzumahaus, A., Huntrieser, H., Isaksen, I. S. A., Jenkin, M. E., Kaiser, J., Kanakidou, M., Klimont, Z., Kulmala, M., Laj, P., Lawrence, M. G., Lee, J. D., Liousse, C., Maione, M., McFiggans, G., Metzger, A., Mieville, A., Moussiopoulos, N., Orlando, J. J., O’Dowd, C. D., Palmer, P. I., Parrish, D. D., Petzold, A., Platt, U., Pöschl, U., Prevot, A. S. H., Reeves, C. E., Reimann, S., Rudich, Y., Sellegri, K., Steinbrecher, R., Simpson, D., ten Brink, H., Theloke, J., van der Werf, G. R., Vautard, R., Vestreng, V., Vlachokostas, C., and von Glasow, R.: Atmospheric composition change - global and regional air quality, Atmos. Environ. 
43, 5268-5350, 2009.

Nawrot, T. S., Torfs, R., Fierens, F., De Henauw, S., Hoet, P. H., Van Kersschaever, G., De Backer, G., and Nemery, B.: Stronger associations between daily mortality and fine particulate air pollution in summer than in winter: evidence from a heavily polluted region in western Europe, J. Epidemiol, Commun. H 61, 146-149, 2007.

Ng, N. L., Kroll, J. H., Chan, A. W. H., Chhabra, P. S., Flagan, R. C., and Seinfeld, J. H.: Secondary organic aerosol formation from $m$-xylene, toluene, and benzene, Atmos. Chem. Phys., 7, 3909-3922, doi:10.5194/acp-7-3909-2007, 2007.

Ng, N. L., Canagaratna, M. R., Zhang, Q., Jimenez, J. L., Tian, J., Ulbrich, I. M., Kroll, J. H., Docherty, K. S., Chhabra, P. S., Bahreini, R., Murphy, S. M., Seinfeld, J. H., Hildebrandt, L., Donahue, N. M., DeCarlo, P. F., Lanz, V. A., Prévôt, A. S. H., Dinar, E., Rudich, Y., and Worsnop, D. R.: Organic aerosol components observed in Northern Hemispheric datasets from Aerosol Mass Spectrometry, Atmos. Chem. Phys., 10, 46254641, doi:10.5194/acp-10-4625-2010, 2010.

Odum, J. R., Jungkamp, T. P. W., Griffin, R. J., Forstner, H. J. L., Flagan, R. C., and Seinfeld, J. H.: Aromatics, reformulated gasoline, and atmospheric organic aerosol formation, Environ. Sci. Technol., 31, 1890-1897, 1997.

Onasch, T. B., Trimborn, A., Fortner, E. C., Jayne, J. T., Kok, G. L., Williams, L. R., Davidovits, P., and Worsnop, D. R.: Soot Particle Aerosol Mass Spectrometer: Development, Validation, and Initial Application. Aerosol Sci. Technol., 46, 804-817, 2012.

Pagels, J., Khalizov, A. F., McMurry, P. H., and Zhang, R. Y.: Processing of Soot by Controlled Sulphuric Acid and Water Condensation Mass and Mobility Relationship. Aerosol Sci. Technol., 43, 629-640, 2009a.

Pagels, J., Wierbicka, A., Nilsson, E., Isaxon, C., Dahl, A., Gudmundsson, A., Swietlicki, E., and Bohgard, M.: Chemical composition and mass emission factors of candle smoke particles, J. Aerosol Sci., 40, 193-208, 2009b.

Paulsen, D., Dommen, J., Kalberer, M., Prevot, A. S. H., Richter, R., Sax, M., Steinbacher, M., Weingartner, E., and Baltensperger, U.: Secondary organic aerosol formation by irradiation of 1,3,5trimethylbenzene- $\mathrm{NO}_{\mathrm{x}}-\mathrm{H}_{2} \mathrm{O}$ in a new reaction chamber for atmospheric chemistry and physics, Environ. Sci. Technol., 39, 2668-2678, 2005.

Platt, S. M., El Haddad, I., Zardini, A. A., Clairotte, M., Astorga, C., Wolf, R., Slowik, J. G., Temime-Roussel, B., Marchand, N., Ježek, I., Drinovec, L., Močnik, G., Möhler, O., Richter, R., Barmet, P., Bianchi, F., Baltensperger, U., and Prévôt, A. S. H.: Secondary organic aerosol formation from gasoline vehicle emissions in a new mobile environmental reaction chamber, Atmos. Chem. Phys. Discuss., 12, 28343-28383, doi:10.5194/acpd-1228343-2012, 2012.
Presto, A. A., Hartz, K. E. H., and Donahue, N. M.: Secondary organic aerosol production from terpene ozonolysis. 1. Effect of UV radiation. Environ. Sci. Technol., 39, 7036-7045, 2005.

Robinson, A. L., Donahue, N. M., Shrivastava, M. K., Weitkamp, E. A., Sage, A. M., Grieshop, A. P., Lane, T. E., Pierce, J. R., and Pandis, S. N.: Rethinking organic aerosols: Semivolatile emissions and photochemical aging, Science, 315, 1259-1262, 2007.

Samy, S. and Zielinska, B.: Secondary organic aerosol production from modern diesel engine emissions, Atmos. Chem. Phys., 10, 609-625, doi:10.5194/acp-10-609-2010, 2010.

Sato, K., Takami, A., Isozaki, T., Hikida, T., Shimono, A., and Imamura, T.: Mass spectrometric study of secondary organic aerosol formed from the photo-oxidation of aromatic hydrocarbons, Atmos. Environ., 44, 1080-1087, 2010.

Schauer, J. J., Kleeman, M. J., Cass, G. R., and Simoneit, B. R. T.: Measurement of emissions from air pollution sources. 5. C-1-C32 organic compounds from gasoline-powered motor vehicles, Environ. Sci. Technol., 36, 1169-1180, 2002.

Schifter, I., Diaz, L., and Rodriguez, R.: Cold-start and chemical characterization of emissions from mobile sources in Mexico, Environ. Technol. 31, 1241-1253, 2010.

Song, C., Na, K. S., and Cocker, D. R.: Impact of the hydrocarbon to $\mathrm{NO}_{\mathrm{x}}$ ratio on secondary organic aerosol formation, Environ. Sci. Technol., 39, 3143-3149, 2005.

Song, C., Na, K., Warren, B., Malloy, Q., and Cocker, D. R.: Impact of propene on secondary organic aerosol formation from $\mathrm{m}$ xylene, Environ. Sci. Technol., 41, 6990-6995, 2007.

Taipale, R., Ruuskanen, T. M., Rinne, J., Kajos, M. K., Hakola, H., Pohja, T., and Kulmala, M.: Technical Note: Quantitative long-term measurements of VOC concentrations by PTR-MS measurement, calibration, and volume mixing ratio calculation methods, Atmos. Chem. Phys., 8, 6681-6698, doi:10.5194/acp8-6681-2008, 2008.

Weilenmann, M., Favez, J. Y., and Alvarez, R.: Cold-start emissions of modern passenger cars at different low ambient temperatures and their evolution over vehicle legislation categories, Atmos. Environ., 43, 2419-2429, 2009.

Weitkamp, E. A., Sage, A. M., Pierce, J. R., Donahue, N. M., and Robinson, A. L.: Organic aerosol formation from photochemical oxidation of diesel exhaust in a smog chamber, Environ. Sci. Technol., 41, 6969-6975, 2007.

Zhang, R. Y., Khalizov, A. F., Pagels, J., Zhang, D., Xue, H. X., and McMurry, P. H.: Variability in morphology, hygroscopicity, and optical properties of soot aerosols during atmospheric processing. P. Natl. Acad. Sci. USA, 105, 10291-10296, 2008. 